\title{
ПУБЛІКАЦІЯ ДОКУМЕНТІВ
}

УДК [94(477.83-25):929І.БОБЕРСЬКИЙ]"1918"

DOI: $10.33402 / \mathrm{nd} .2020-8-185-211$

\author{
Андрій СОВА \\ кандидат історичних наук \\ дочент кафедри олімпійської освіти \\ Львівського державного університету \\ фізичної культури імені Івана Боберського \\ ORCID: https://orcid.org/0000-0003-0548-4975 \\ e-mail: andrijsova@yahoo.com
}

\section{ІВАН БОБЕРСЬКИЙ І ЛИСТОПАДОВІ ПОДІЇ У ЛЬВОВІ 1918 РОКУ}

Вперше на основі різнопланових джерел: документів Центрального державного архіву вищих органів влади і управління України, Центрального державного історичного архіву України у Львові, Українського католицького університету, «Збірки воєнних друків» Наукової бібліотеки Львівського національного університету імені Івана Франка; «Дневника» Івана Боберського; приватного архіву Степана Гайдучка (м. Львів); періодичних часописів «Діло» та «Вістник Державного Секретаріяту Військових Справ»; спогадів осіб, які безпосередньо чи опосередковано знали Івана Боберського, досліджено участь Івана Боберського у листопадових подіях 1918 р. у Львові. Із залученням раніше не доступних та малознаних документів реконструйовано його діяльність у цей період. Доведено, що саме Іван Боберський взяв активну участь у новоствореній Українській державі - Західно-Українській Народній Республіці (ЗУНР). Висвітлено його діяльність у Державному секретаріаті військових справ (ДСВС) ЗУНР під керівництвом Дмитра Вітовського. Звернено увагу на його ініціативи зі створення «Письменничого відділу» ЗУНР, який він очолив, розроблення документації (правильника до впоряду, афіш, наказів, виказок, інформацію про платню для вояків тощо), працю над «Вістником Державного Секретаріату Військових Справ». Наголошено на його важливій праці у контексті фотофіксації подій, що дала можливість залишити для нащадків документальні свідчення про перебіг польсько-української війни. Методологія дослідження грунтується на принципах об'єктивності, достовірності, комплексності та науковості. 3 огляду на інформативність опубліковано витяги з «Дневника» Івана Боберського за період з 1 листопада до 21 листопада 1918 p.

Ключові слова: Іван Боберський, Львів, Західно-Українська Народна Республіка, Державний секретаріат військових справ ЗУНР, «Письменничий відділ» ДСВС ЗУНР, польсько-українська війна 1918-1919 pp.

У листопадові дні 1918 р. українці творили свою незалежну державу з центром у Львові під назвою Західно-Українська Народна Республіка. Іван Боберський, як і багато інших знаних громадсько-політичних діячів того часу, був серед тих, хто брав активну участь у цьому процесі. Українська історіографія представлена багатьма працями, в яких 
висвітлюються листопадові події у Львові 1918 р. . . Однак окремої розвідки про діяльність Івана Боберського у цей період немає. 3 огляду на це підготовлено нашу публікацію.

Метою статті є комплексне дослідження діяльності Івана Боберського упродовж 1-21 листопада 1918 р. у Львові, коли творилася українська держава - ЗУНР.

Джерельною базою для дослідження стали: документи Центрального державного архіву вищих органів влади і управління України, Центрального державного історичного архіву України у Львові, Українського католицького університету, «Збірка воєнних друків» відділу рукописних, стародрукованих та рідкісних книг ім. Ф. П. Максименка Наукової бібліотеки Львівського національного університету імені Івана Франка; «Дневник» Івана Боберського; світлини з листопадових боїв за Львів, які збереглися у приватному архіві учня і послідовника Івана Боберського Степана Гайдучка (м. Львів); часописи «Діло» та «Вістник Державного Секретаріяту Військових Справ»; спогади.

1 листопада 1918 р. Іван Боберський займався демонтажем експозиції воєнної виставки Українських січових стрільців, яка пройшла у Львові з 15 вересня до 31 жовтня 1918 р. у Національному музеї по вул. Мохнацького (тепер вул. М. Драгоманова)². Атмосферу, яка панувала того дня у Львові, він описав у своєму «Дневнику»: «Дня 1.XI.1918 [р.], Львів, пятниця, Цілу ніч лляло. Чути стріли. Слуга в камениці кличе: “Революція стріляє”. Йду до Музея прятати, бо кімнати мають бути свобідні. Знімаємо малюнки, світлини, гарно викінчену карту походів Лєгіону через Карпати в напрямі Галича, велику знимку [Теофіла] Мойсеовича коло Семиківців, що вражає кожного видця глибиною простору. Працюємо цілий день до 8-мої вечером. Добрянський Антін дуже пильний, помагає неструдимо, Фронзей Володимир не прийшов пополудні. Гриневич цілком не приходив. В полуднє заглянув я по місті. На вежі ратуша синьо-жовтий, великий прапор, в ринку сторожать українські вояки. По вулицях прибитий маніфест, що власть над містом находиться в руках Української Національної Ради. Склепи зачинені. Нині задушний день. Люди поденервовані, йдуть вулицею й оглядаються поза себе. На Академічній площі виджу 5 вояків з крісом в правій руці провагом. «Діло» й «Українське слово» вийшли кілька годин скорше, чим звичайно. Намісник інтернований, стрільці походують на Львів»³.

На запрошення Дмитра Вітовського, тодішнього державного секретаря ДСВС ЗУНР, Іван Боберський почав працювати у Державному секретаріаті військових справ

1 ЗУНР, 1918-1923: Ілюстрована історія. Львів; Івано-Франківськ: Манускрипт, 2008. 524 с.; Дєдик О. Бої у Львові. 1-21 листопада 1918 року. Львів: Вид-во «Астролябія», 2018. Ч. І. 192 с. (Серія: Бібліотека «Цитаделі») та ін.

2 Відкриття вистави УСС. Діло (Львів). 1918. 17 вересня (4 ст. ст.). Чис. 211 (9771). С. 2-3; Вистава малюнків і сьвітлин «Артистичної Горстки» $\mathrm{i}$ «Пресової Кватири». Діло. 1918. 18 вересня (6 ст. ст.). Чис. 212 (9772). С. 3; Там само. 20 вересня (8 ст. ст.). Чис. 214 (9774). С. 4; Там само. 16 жовтня (3 ст. ст.). Чис. 235 (9795). С. 4; Там само. 31 жовтня (18 ст. ст.). Чис. 248 (9808). С. 3 ; Центральний державний історичний архів України, м. Львів (далі - ЦДІАЛ України). Ф. 366. Оп. 1. Спр. 7. Арк. 60; Сова А. Військово-політична діяльність Івана Боберського в роки Першої світової війни. Гуманітарні дисципліни у навчально-виховному прочесі вищих навчальних закладів: зб. наук. статей. Львів: ПП Сорока Т. Б., 2014. Вип. 4. С. 90-100.

3 Центральний державний архів вищих органів влади і управління України (далі - ЦДАВО України). Ф. 4379. Оп. 1. Спр. 21. Арк. 37. 
ЗУНР. Про перші дні цієї діяльності він залишив спогад у своєму щоденнику: «На вулиці Валовій стрінув мене [Дмитро] Вітовський. Налягає дещо на ногу. На лиці якийсь заклопотаний. Випрямлююсь і дашкую на привіт. Задержується і я пристаю. “Перейдім до будинку намісництва, маю вам дещо сказати”. Ми зайшли на перший поверх до якоїсь високої кімнати. “Сідайте, будемо говорити”. Зміст розмови був такий, щоб я обняв часопис Військового Секретаріяту, військові видання і поміг моїм досвідом, де буду міг і буду уважав за відповідне» ${ }^{4}$. ДСВС очолювали спочатку полковник Дмитро Вітовський (з 9 листопада 1918 р. до 13 лютого 1919 р.), потім полковник Віктор Курманович (з 16 лютого до 9 червня 1919 р.).

Івана Боберського більше приваблювала робота в секретаріаті освіти ${ }^{5}$. 3 цьго приводу 14 листопада 1918 р. він занотував у щоденнику: «Непокоїть мене, що я опинився на бажанні [Дмитра] Вітовського у Воєннім міністерстві. Моє місце в Міністерстві освіти. Обавляюсь, що з моєї роботи нічо не буде, як будуть мене ставити там, де не розумію роботи, як слід. Але тепер є час на війну і не на освіту. Мус воювати. Смішно, що я в одязі і в степені простого січового стрільця. Старшини в бюрі дивляться скоса. Перелякані простим вояком» ${ }^{6}$.

Наступного дня Іван Боберський у друкарні «Діла» отримав кошторис на видання «Правильника» $\mathrm{i}$ «Вістника» і попрямував на зустріч із Дмитром Вітовським до приміщення Галицького намісництва. Там у розмові з Дмитром Вітовським він запропонував назву для майбутнього друкованого органу ДСВС ЗУНР - «Вістник Державного Секретаріату Військових Справ», що й була затверджена. 15 листопада 1918 р. Іван Боберський уклав «начерк обов’ язків» (положення) для відділу, яким мав керувати, назвавши його «Письменничим відділом» ${ }^{7}$. Від того дня він почав працювати над «Вістником Державного Секретаріату Військових Справ» та виконувати обов'язки, передбачені положенням керівника відділу.

Уже на початковому етапі праці у ДСВС, що збігся з початком польськоукраїнської війни, за досить складних умов Іванові Боберському вдалося зробити чимало. Він не лише займався документацією секретаріату, а й готував та редагував розпорядження, частину з яких публікували в українських часописах. Так, 16 листопада на сторінках «Діла» 3' явилися «Розпорядки ДСВС, ч. 1-5» від 13 листопада ${ }^{8}$. У своєму щоденнику Іван Боберський зазначив: «Я написав в заголовку "Розпорядження", М[ихайло] Возняк в “Ділі” поправив на “Розпорядки”, а після мене повинно бути “Розпоряди”»". Крім того, Іван Боберський готував до друку правильник до впоряду, афіші, накази, виказки та інформацію про платню для вояків тощо. Зокрема, 15 листопада 1918 р. він підготував такі документи: «Платні для офіцирів, урядників і мужви війська Західно-української Народньої Республики», «Харч. Одна пайка» (добова

\footnotetext{
${ }_{4}^{4}$ ЦДАВО України. Ф. 4379. Оп. 1. Спр. 21. Арк. 45.

5 ЦДІАЛ України. Ф. 366. Оп. 1. Спр. 7. Арк. 59-59зв.

${ }^{6}$ ЦДАВО України. Ф. 4379. Оп. 1. Спр. 21. Арк. 47.

7 Там само. Арк. 46.

8 Розпорядки Державного Секретаріяту Військових справ 3 дня 13 падолиста 1918. Діло. Львів, 1918. 16 падолиста (3 ст. ст.). Чис. 263 (9823). С. 1-2.

9 ЦДАВО України. Ф. 4379. Оп. 1. Спр. 21. Арк. 48.
} 
норма продовольчого забезпечення вояка) та ін. ${ }^{10}$. Текст, підготовлений «недолугим складачем» для виказки, Іванові Боберському довелося змінити ${ }^{11}$.

Чимало уваги Іван Боберський приділив фотографуванню, прагнучи залишити для нащадків документальні свідчення про перебіг польсько-української війни. Згодом, уже як представник уряду ЗУНР у США та Канаді, він експонував частину світлин, зроблених у цей час, українським емігрантам ${ }^{12}$. У приватному архіві Степана Гайдучка збереглося 36 світлин $^{13}$, на яких зображені українські вояки на позиціях, основні будівлі, в яких працювали керівні органи ЗУНР, будівлі після обстрілів, укріплення на вулицях Львова, поранені та вбиті вояки тощо. Завдяки записам Івана Боберського у щоденнику можемо встановити точні дати окремих фотографій та обставини, в яких проводили зйомку ${ }^{14}$.

У неділю 17 листопада 1918 р. о $9^{30}$ біля будинку, де за Австро-Угорщини розташовувалося Галицьке намісництво, присягу на вірність ЗУНР склали перші вісімнадцять осіб, серед них Іван Боберський, Петро Бубела та Дмитро Вітовський ${ }^{15}$. Слова присяги звучали так: «Присягаю торжественно Всемогучому Богу на вірність і посвяту Західно-Українській Народній Республиці, Її верховній Владі, Ї̈̈ Правительству, Її Армії і затвердженим законам. Присягаю як жандарм Західно-Української Народньої Республики сповняти совісно припадаючі на мене або приділені мені обовязки в службі над загальним порядком, спокоєм і безпеченьством після дотичних приписів і після військових законів і заряджень, які мене обовязують як вояка. Присягаю дбати лише про добро служби і Західно-Української Народньої Республики, повинувати ся радо наказам покликаних до сього урядів та моїх зверхників і зберігати вірно службову тайну. Так мені Боже допоможи!» ${ }^{16}$. На одному 3 друкованих примірників присяги збереглися помітки Івана Боберського олівцем, які свідчать, що він виконав коректуру тексту ${ }^{17}$. Це підтверджено і його записом у щоденнику від 17 листопада ${ }^{18}$.

Психологічний стан Івана Боберського у листопаді 1918 р. найкраще передають його записи у «Дневнику», датовані 5 листопада: «Такий виступ 3 крісом до бою

\footnotetext{
${ }^{10}$ ЦДАВО України. Ф. 2192. Оп. 2. Спр. 11. Арк 1, 2.

11 Там само. Ф. 4379. Оп. 1. Спр. 21. Арк. 51.

${ }^{12}$ Сова А. Діяльність Івана Боберського як повноважного представника уряду Західно-Української Народної Республіки у США та Канаді. Дрогобицький краєзнавчий збірник / ред. кол. Л. Тимошенко (голов. ред.), Л. Войтович, Г. Гмітерек та ін. Дрогобич: Посвіт, 2019. С. 134-153.

${ }^{13}$ Світлини. Приватний архів Степана Гайдучка (м. Львів).

14 Завдяки записам Івана Боберського та збереженим світлинам нещодавно вдалося допомогти родині Михайла Машталіра, яка мешкає у Львові та Львівщині, з'ясувати обставини загибелі їхнього родича.

${ }^{15}$ ЦДАВО України. Ф. 2192. Оп. 2. Спр. 11. Арк. 50.

${ }^{16}$ Наукова бібліотека Львівського національного університету імені Івана Франка, Відділ рукописних, стародрукованих та рідкісних книг ім. Ф. П. Максименка, «Збірка воєнних друків». Од. зб. 693 (Слово присяги для жандармів (офіцирів; мужви) Західньо-Української Народньої Республики. [Листівка]. Арк. 1).

17 Західно-Українська Народна Республіка в документах і матеріалах Наукової бібліотеки Львівського національного університету імені Івана Франка: альбом-каталог / упоряд. Ю. Лисий, М. Ільків-Свидницький. Львів, 2018. С. 37, 114.

${ }^{18}$ ЦДАВО України. Ф. 4379. Оп. 1. Спр. 21. Арк. 50.
} 
поділає на нашу смирну вдачу, на український тихий мозок. Боротьба розбуджує відвагу і рішучість. Хотяйби ця війна не скінчилась успішно, то на всякий случай буде мати вплив на наше дальше поведення. Дотепер воювали українці для других, тепер рішились ми воювати лишень для нас. Будемо інакше ставитись до ворогів і вороги зрозуміють, що посідаємо завзяття до виступу з оружжям» ${ }^{19}$.

21 листопада 1918 р. Іван Боберський разом з урядом ЗУНР покинув Львів і до 7 грудня перебував у Тернополі. 29 листопада 1918 р. він був іменований четарем українського війська ${ }^{20}$. Збереглася грамота такого змісту: «До Івана де Боберського референта Письменничого Віддїлу Державного Секретаріяту Військових Справ. Тернопіль. Тернопіль 29 падолиста 1918 [р.]. Нинїшною грамотою іменую Івана де Боберського четарем Українського Війська. Державний Секретаріят Військових Справ. /Дмитро Вітовський/» ${ }^{21}$.

У Тернополі Іван Боберський продовжив свою діяльність у «Письменничому відділі» ДСВС ЗУНР. Його напрацювання, зроблені у Львові, завершилися успішним виданням першого числа «Вістника Державного Секретаріяту Військових Справ» ${ }^{22}$. Про період діяльності Івана Боберського у Тернополі та Станіславові (тепер - місто Івано-Франківськ) готується окреме наукове дослідження.

Завдяки тому, що Іван Боберський вів щоденні записи, отримано важливе джерело для відтворення подій становлення ЗУНР та перших місяців боротьби за державність. «Дневник» Івана Боберського охоплює час від 15 вересня 1918 р. до 22 травня 1919 р. Перебуваючи в еміграції, спочатку у Канаді, а з 1932 р. - у Югославії, Іван Боберський упорядкував щоденник (22 жовтня 1944 р. - кінцева дата упорядкування записів) й один примірник надіслав до «Українського музею» в Празі (цей примірник згодом опинився у ЦДАВО України ${ }^{23}$ ), другий - до Національної бібліотеки у Відні, третій - до Осередку української культури і освіти у Вінніпезі ${ }^{24}$. У 2003 р. третій примірник «Дневника» Івана Боберського упорядкував та опублікував Юрій Мицик ${ }^{25}$. На сьогодні вдалося віднайти два примірники «Дневника», що зберігаються у Києві та Вінніпезі. 3 огляду на те, що Юрію Мицику в окремих випадках не вдалося коректно відчитати машинописний текст з рукописними правками Івана Боберського,

${ }^{19}$ ЦДАВО України. Ф. 4379. Оп. 1. Спр. 21. Арк. 41-42.

${ }^{20}$ ЦДАВО України. Ф. 2188. Оп. 2. Спр. 44. Арк. 361; Спис іменовань у війську Західної Области Української Народньої Республики, від дня 1.XI.1918 почавши, до 1 січня 1919 включно. $B i$ стник Державного Секретаріяту Військових Справ. Станиславів, 1919. 31 січня. Ч. 5. С. 3; Виказка чет. Івана Боберського, як референта Секретаря Військових Справ. За волю Украӥни. Історичний збірник УСС. В 50-ліття збройного виступу Украйнських Січових Стрільиів проти Москви. 1914-1964. Нью-Йорк: Видання Головної Управи Братства Українських Січових Стрільців, 1967. С. LX.

${ }^{21}$ ЦДАВО України. Ф. 2188. Оп. 2. Спр. 44. Арк. 361; [Грамота іменування Івана Боберського четарем Українського Війська]. Арк. 1. Архів Українського Католицького Університету.

22 Вістник Державного Секретаріяту Військових Справ (Тернопіль). 1918. 1 грудня. Ч. 1.4 с.

${ }^{23}$ ЦДАВО України. Ф. 4379. Оп. 1. Спр. 21. 183 арк.

${ }^{24}$ Боберський I. Дневник 15.IX.1918-22.V.1919. 182 арк. Осередок українськой культури і освіти у Вінніпезі.

${ }^{25}$ Боберський І. Щоденник, 1918-1919 рр. / упоряд. Ю. А. Мицик. Київ: Вид. дім «КМ Академія», 2003. $260 \mathrm{c}$. 
публікуємо витяги з «Дневника» Івана Боберського за період 31 до 21 листопада 1918 р. $з$ примірників, які зберігаються в Осередку української культури і освіти у Вінніпезі та у Центральному державному архіві вищих органів влади і управління України $^{26}$, із збереженням лексичних і орфографічних особливостей.

Отже, після проголошення ЗУНР, початку польсько-української війни 19181919 pр. у житті Івана Боберського розпочався новий етап. Він поринув у державне будівництво новоствореної Української держави. Зокрема, організував і очолив «Письменничий Відділ» у Державному Секретаріаті Військових Справ ЗУНР, де зайнявся розробкою різної документації (правильника до впоряду, афіш, наказів, виказок, інформації про платню для вояків тощо). Важливою у його діяльності в цей період була праця над «Вістником Державного Секретаріату Військових Справ» ЗУНР. І хоч перше його число вийшло друком 1 грудня 1918 р. у Тернополі, однак саме у Львові Іван Боберський розпочав роботу у цьому напрямі. Важливу працю він проводив у контексті фотофіксації подій, що дало можливість залишити для нащадків фотодокументальні свідчення про перебіг воєнних дій у Львові у листопаді 1918 р. «Дневник» Івана Боберського за період з 1 листопада до 21 листопада 1918 р. $\epsilon$ одним із унікальних джерел того часу, який передає атмосферу у Львові та умови, в яких творилася ЗУНР.

\section{Витяги 3 «Дневника» Івана Боберського за період 31 листопада до 21 листопада 1918 р.}

Дня 1.XI.1918, Львів, пятниия ${ }^{27}$

Цілу ніч лляло. Чути стріли. Слуга в камениці кличе: «Революція стріляє». Йду до Музея прятати, бо кімнати мають бути свобідні. Знімаємо малюнки, світлини, гарно викінчену карту походів Лєгіону через Карпати в напрямі Галича, велику знимку Мойсеовича коло Семиківців, що вражає кожного видця глибиною простору. Працюємо цілий день до 8-мої вечером. Добрянський Антін дуже пильний, помагає неструдимо, Фронзей Володимир не прийшов пополудні. Гриневич цілком не приходив. В полуднє заглянув я по місті. На вежі ратуша синьо-жовтий, великий прапор, в ринку сторожать українські вояки. По вулицях прибитий маніфест, що власть над містом находиться в руках Української Національної Ради. Склепи зачинені. Нині задушний день. Люди поденервовані, йдуть вулицею й оглядаються поза себе. На Академічній площі виджу 5 вояків 3 крісом в правій руці провагом. «Діло» й «Українське слово» вийшли кілька годин скорше, чим звичайно. Намісник інтернований, стрільці походують на Львів.

\footnotetext{
${ }^{26}$ ЦДАВО України. Ф. 4379. Оп. 1. Спр. 21. Арк. 37-55; Боберський I. Дневник 15.IX.191822.V.1919. Арк. 37-55. Осередок украӥнської культури і освіти у Вінніпезі.

${ }^{27}$ Тут і далі дописані слова виділені курсивом.
} 
Дня 2.XI.1918, Львів, субота

Рано пакую предмети 3 вистави. Директор Святицький ${ }^{28}$ хоче мати свобідні кімнати. Добрянський помагає. Звиваємось, щоб скорше.

На обід йду до Вовка, який все повторює: «Коби лишень стрільці прийшли». Опісля пішов я вулицями. Сторожі ніде нема, хіба в ринку. Це робить зле вражіння, бо українські стійки повинні б стояти всюди, де цего вимагає вуличний рух. Це бувби доказ, що місто в українських руках. Йду Руською вулицею. Йде брат Миколи Левицького в однострою фельдфебля від поліції. Йду з ним до Народного Дому. В дверях від Вірменської вулиці стрічає нас Микола Мороз, що знимає рух перед брамою. В сінях надибую Кринжаловича з відкритою головою з папіросом в губі. Щось говорить, питає. На вулиці стоїть самохід, подальше попри Промисловий музей стоїть тягаровий самохід, вояки сидять на нім. Мають синьо-жовті кокардки замість гузика з буквами F. J. I. або відзнаку «Соборна Україна», яка робить двома ріжками добре вражіння. На відзнаці св. Михайло підносить правою рукою меч, а в лівій держить щит з Львом для оборони. Ми перейшли через мале обійстя у головні сіни. Ворота на вулицю були замкнені. Тут в сінях стояла громада вояків, видно гуртки до зміни сторожі по місті. Ми вийшли на I. поверх, там де «Бесіда», і перейшли в «Читальню». Сиділа там якась пані, вештались офіцири в чорних офіцирських шапках, при дверях до слідуючої кімнати стояло двох людей $з$ наїженими крісами в пів цивільнім і пів військовім платтю.

Кажу до Левицького: «Хотівбим знати лишень, коли прийдуть стрільці, більше нічо». Левицький відповідає: «Горук вийде сюди на папіроску». Поглянув я до другої кімнати. Сидить там якийсь сивоволосий військовий. «Хто це $\epsilon ? »$ Левицький каже: «Обершляйтнант Маринович». Виджу оберляйтнанта Мечника. Витаюсь i кажу: «Вони тут певно дадуть вам працю». Мечник відповідає: «Добре, добре, але я не придамся їм дуже». Якийсь молодий офіцир в чорній шапці питає мене: «Пан професор пізнають мене?» «Чому ніт, - відповідаю, - Рогуцький». Він мірить мене очима, дивиться на мій плащ, який дуже парадно виглядає, бо зроблений зі сукна 1915 р. і скроєний знаменито. Глядить на мою рожу на шапці і на барчики на раменах. Пізнає, що я мужвак, не старшина і робить дуже зимну міну. Питається мене, де я є. Відповідаю: «При Центральній Управі Лєгіону у Відні, але тепер уладжував я стрілецьку виставу у Львові і закінчую їі». Він відступив від мене холодно.

Українець в очнику, що дав мені раз хліба на військовій харчівні, вибігає з кімнати, стереженої сторожею, з картками в руці і каже голосно: «Це безличність, жадають пропусків». Дивує мене, чому безличність. Але не питаю про причину. Виходить Горук із своїм дитинячим, милим усміхом і смоктає папірос. Говорить 3 кимсь, але я не зближуюсь. 3 розмови присутних вичуваю, що стрільців ще нема. Мечник каже: «Замало людий, замало». То чує кожний. Я вийшов, бо чогож буду тут заваджати. В салі виджу Величкову. Чого вона тут чекає? Йду ганком. В салі для санітарної помочі стоїть Скоморовський з торбинками. В салі, де було дня 18.Х. засідання послів про відлучення від Австрії, лежать кріси з насадженими ножами. Сторожа каже: «Неможна входити». 3 ганку гляджу на подвіря з сірими, неприємними стінами. Лежать на долині підкладки на хребет коня, що носить стріловину і скоростріл, якісь цівки, скриньки з набоями. Сходжу з першого поверха наділ, виджу коня від скоростріла.

\footnotetext{
${ }^{28}$ Йдеться про Іларіона Свєнцицького.
} 
Стрічаю Чумаківну в пластунськім капелюсі із задертою з боку крісою. Чого буду заваджати тут серед цієї товпи знаних і незнаних людей світських і військових? Все йде після військового степеня не після досвіду і ужиють мене зараз як онучу. Страчу вповні свободу руху і рішання. Надпоручник Кордуба говорив мені в кімнаті про військовий суд, що він радо розібравби з другими цю роботу. Але я не можу рішати. Тут нема господара, а я ним не можу стати, бож тут господарить Національна Рада. Десь вона $\epsilon$, але тут не виджу її представника. Догадуюсь, що приказує Маринович а Горук при його боці.

Пійшов я Трибунальською вулицею. Коло склепу Шафа стоїть сторожа, якихсь двох в цивільних плащах з крісами. Так само, коли я йшов до Народного Дому, то на розі Ринку і Краківської вулиці стояв один вояк, а один в загортці з синьо-жовтою опояскою. А один сидів при стіні і їв з мищини ложкою юшку. Видно, що повстанцям не удалось приєднати вояків 3 касарень. Свобода прийшла нагло, нарід несвідомий своїх прав. Виджу прибиту відозву Української Національної Ради в польській мові. Маніфест про защиту всіх горожан.

Вернув я до Музея, застав Добрянського і ми пакували. На вечерю вийшов я скорше, бо вчора прийшов перед замкнені двері. Приніс я два медівники для Добрянського. Зайшов однак ще на короткий час до каварні Сансусі на часописі. Читаю, якийсь панок зближається до мого столика, показує на котрийсь часопис і каже: «Czy mogę prosić?». Відповів я дуже ввічливим тоном: «Прошу дуже, свобідне». «Nie rozumię, wolne?» - відповів панок, взяв часопис, вернув до свого стола і говорив голосно до пивничого: «Панімаєтє? Ето істінно рускі народ. Маєте гаваріть только па рускі. 3 мной нє шуткі». Повтаряв це кілька разів, голосно на цілу порожню каварню, бо сидів в ній лишень він і я. Пивничий нічо йому не відповідав, але коли приносив мені каву, запитав зниженим голосом: «Чи безпечно?» - Успокоюю його відповіддю: «Стійки ходять, длячого малоб бути небезпечно». Часописі прочитані, плачу вісім і пів корони, одягаю плащ, припоясую ремінь з багнетом, надіваю мазепинку на голову. Панок дивиться люто, але нічо не говорить. Я також нічо не кажу і виходжу мовчки 3 каварні. Спішусь до Музея, де пакуємо до 9-тої години. Добрянський відходить домів, хотяй немає пропуска. Не боїться. Переходжу містом, щоб глянути на вулиці. Двері домів замкнені вже від 6-тої години вечером, бо тепер стан облоги. Перейшов я Академічною вулицею до готелю Жоржа. Вікна освітлені, неначе на Святий Вечір. Люди видно не сплять, говорять, читають, числять. На вулиці нікого, на Марійській площі нікого. Переїздить якась дорожка по вибоях брукованої вулиці. Переходить український стійковий, дивиться на мене з боку. Але не зачіпає. Вертаю. Якихсь двох недоростків на розі вулиці Хорушини йдуть попри мене. Коли минули мене, стрілив оден, але гук слабий, видно револьвер невеликий. Гонити за ним? Шкода труду. Пійшов я поволи, глядячи на освітлені вікна Львова, який не може заснути. Гук стрілів йшов десь від Цитаделі, попри котру переходжу вулицею Мохнацького, щоб зайти на вулицю Супінського ч. 26.

В часописях читав я, що Райнлєндер інтернований, а директором поліції став д-р Стефан Баран. Предсідником міністрів є д-р Кость Левицький. О годині 9.30 пішов я спати. 
Дня 3.XI.1918, неділя, Львів

Йду на снідання до Вовка. Дві кави і медівник 3 корони. Питаю Вовка: «Робили ви вчера службу?» - «Був я до 8-мої в Народнім Домі. Надїхали фаєрвахи і їх наші гальмували. Стрілили, бо не хотіли станути, а потім їх завернули. А одного з наших вбили, таки наші». Не питаю дальше, бо це вже може бути видумка, щоб щось нечуваного оповісти.

Перед полуднем пакуємо образи дальше. Куплені вчора часописі не мав я часу читати. Нині купив я лише «Kuryer». Пише про переговори між поляками а українцями, щоб прийшло до порозуміння. Вже вчера вичитав я назвище Вітовського як команданта міста. Це той, котрого Боєва Управа іменувала отаманом. В часописях його відозва підписана справді $з$ назовом «отаман». Дощ цюрить, але люди ходять жваво. Якась міщанка з білим орлом під шиєю каже: «Tо długo nie potrwa». Купую «Wiek nowy» i «Wieczorna gazeta»: «Polacy opanowali dworzec, Politechnikę i gmach žandarmeryi». Слуга Олександер оповідає, як йшов площею св. Юра: «Їхало авто, а на переді машиновий кріс на трьох ніжках. Кілька разів стрілили. Потім поїхали десь під Стрийський парк».

По обіді Добрянський не прийшов, бо мав вчора велику пригоду: «Вчера заняв мене вояк і попровадив до Народного Дому, бо я не мав пропуску. А він взяв мене за жида. Я спав в Народнім Домі. Там були мої товариші. Той, що тут зі мною пакував, дістав кріс і набої і служить на варті». Я порядкував сам і виносив образи, позавивані в папір і обвязані мотузком на балькон, щоб там стояли і не заважали в долині. О годині 5.30 пійшов я на вечерю, але Вовк вже замкнений. Ліхтарні на вулиці Мохнацького не світять. Темно. Лишень на св. Николая і на Академічній видно поломінь ліхтарень. Дощ, дощ. Купую у Стецькова 7 тісточок на вечерю за 7 корон, їм по дорозі. Надійшов пан і пані: «Куди на вулицю Калєчу?» Пізнаю, що жиди. Говорять по-українськи. «А чи безпечно?» Питають перестрашені, бо від вулиці Яблоновських чути гук стрілів, від Цитаделі також. Кажу: «Це якісь вуличники позваляють собі на стріли з револьвера. Але трафити можуть». Підводжу їх направо, йдуть опісля в долину. Вертаю до Музея, складаю дальше образи і рисунки, завиваю і порядкую. Приходить Олександер. «Котра година?» - питаю. «Пів до семої». - «То я посиджу ще до 8-мої і пійду». Я сів і пишу власне опис нинішнього дня.

3 городу графа напроти чути постійно гук револьвера. Хтось заліз там і стріляє. Від касарні Яблоновських чути гук кріса, з Цитаделі також гук кріса. Чи це наша варта пригадується, чи чужі страшать? Жид, що йшов 3 жидівкою, сказав: «Ми приїхали зі Стрия, висіли на Перзенківці, не на головнім двірці». Маю покінчити 3 виставою, перепровадити обстанову з помешкання при Супінського, 26. Ще ціле бюро «Центральної Управи» у Відні треба звинути, щоб я міг переїхати на постійний побут, чи на постійну війну до Львова. «Gazeta Wieczorna» пише, що польський лєгіон ставив перший опір зі школи Сінкевича коло костела св. Єлисавети, а потім коло костела св. Анни. Оба двірці обсаджені. Рух поїздів перерваний. Телєграф не робить. Нема вісток з Европи про мирові переговори. Коли це пишу, рокочуть стріли за Музеєм з Цитаделі, бо ж Музей стоїть при самій Цитаделі. Пишу у високій сіни Музея при двох елєктричних жарівках. Холодно тут. Великі церковні образи глядять на мене, а сягають рядами аж під стелю, давні памятки з українських церков, різблені стовпці і стовпи, царські ворота з іконостасів блистять мутним золотом, золотисті крила i голови ангелів видніють із сумерку високого простору. 
В часописі подане, що поляки пруть від школи Сінкевича в долину до міста, а українці ставляють завзятий опір.

Дня 4.XI.1918, Львів, понеділок

Стрілянина на Цитаделі через цілу ніч, скорше або повільнійше, з крісів, із скорострілу. Чути стріли револьверові з городу. Якийсь рубака не хоче заснути. Доперва над раном заснув я трохи, а встав три чверти на девяту, щоб зайти зараз до Музея. Добрянський прийшов і ми витягнули три найбільші образи через високу складану драбину, щоб зложити на бальконі. Рисунки і малюнки Куриласа, Іванця, Старчука, Геца, що не були в рамах, зложили ми в обкладинки або позвивали у звої.

При обіді у Вовка обслугує новий пивничий в темно-синім одінню. Польської дівчини Стефці вже нема. Здається, що пішла на революцію. Хочу зайти до «Діла». Йду з обіду вулицею Панською, Бернардинською площею, вулицею Боїмів на Ринок. Тут стоїть варта, пускає дальше. Виходжу до друкарні. Питає директор Айхельбергер: «Чи є стрільці?» - «Нема». - «Чому нема?» - «Незнати. Подайте ласкаво це письмо пана Святицького до друку». - «Добре, аж завтра, бо число скінчене. Редакція замкнена, всі вийшли. Чи дійсно нема вісток про поміч?» - «Нема, - кажу немилосердну правду заклопотаному директорові друкарні. - «Це лишень у німців йде всьо точно, мусить йти, йде на час». Один зі складачів показує мені кулю, що впала до салі складачів через вікно. Сходжу сходами на діл, на Ринок. Виджу Гайдучка, як пояснює щось воякові, витягає револьвер в праву руку і йде дальше. На розі вулиці Руської і Ринку вартові оживились: «Хтось стріляє з Кармелітів». Оглядаюсь на велику скриню Ратушеву з чотиригранною, несмачною вежею. Синьо-жовтий прапор повіває дальше на верху. Ратушева будівля все мене разила своєю бридотою. Тепер вона прикрасила свою сірину блакитом і золотом нового прапора. Нечувана, недозволена, заказана прикраса. Коло входу до ратуша розставлені вояки. Скоростріли. Йду вулицею Боїмів. Дві черги вояків з крісами в руках йдуть по обох боках вулиці в напрямі готелю Жоржа. Гук стрілів від Марійської площі. Гук стрілу від одного 3 їдучих вояків. Виглядає на облаву на тигрів. Переходжу на вулицю Камінну а відти на вулицю Фредри. Цікаві глядять то на мене, то на вояка, що минає мене з наїженим багнетом і йде дальше. Не оглядаюся за ним. Ступаю спокійно Академічною площею, заходжу до цукорні Стецькова при вулиці св. Николая на чай. Стецьків питає: «Де мешкаєте?» - «При вулиці Супінського, 26». - «Цеж при Цитаделі, небезпечно». «Нічо не поможе. Так або так, все одно». - «Але чи при нас вже ліпше?» - «Поміч приходить постійно, - говорю йому, - щоб не страшити непотрібно». - «Вже ліпше, щораз ліпше». Випиваю чай, плачу і виходжу. Заглядаю до мешкання Горука. Кажуть мені: «Не приходив спати».

В Музею пишу спис перехованих образів. Директор Святицький питає за часописами. Подаю «Вєк», що я його купив у рознощика за 30 сотиків. Читає і випитується: «Надійшла поміч?» Відповідаю, що помочі все ще нема: «Українці спізнюються на бал, до театру», - успокоюю його. - «То ви хотілиб, щоб не спізнились на війну. Вони цього не зроблять». Ученик Добрянський приходить і каже, що завтра не прийде, бо дає черевики до шевця, а швець направляє кілька днів. Якийсь совісний хлопчина. Другий неприйшовби і конець, не повідомлявби наперед. Пощо?

Пишу ці стрічки в величавій сіни Музея. Це мала бути палата професора університету. Але не докінчив, бо не стало йому гроша. Чисто по польськи. Не числить наперед, 
зачинає виставно, розсипає гроші, кінчить порожною мошонкою і продажію дому. Митрополит Шептицький купив цю палату на Український Національний Музей. При отворинах промовляли в тим сіни ряд промовців, між ними говорив я від українських руховиків. Найкращу, бо вповні природну і горячу промову виголосила учителька української приватної школи Малицька. Вжалила дещо присутних представників австрійськопольської влади, а це нам все подобається. Любимо допечи навіть на празник.

На цитаделі зачинають гудіти стріли, шибеник в городі графа при вулиці Мохнацького знова грюкає з револьвера. Загасив я всі жарівки а пишу при одній. Куди тепер йти? У мене світла нема. Відвідати вуйка Тита Реваковича? Всі там настрашаться. Пійду таки домів. Але перше напишу ще листа до жени у Відні. Пишу: «Львів, дня 4.XI.1918, понеділок, вечером 6-та година в Музею. Дорога Бараболе! Даремно чекаємо на поміч. Ані Лєгіон, ані який-небудь відділ не приходить, щоб помогти в бою. Це недбальство не можна зрозуміти. Місто гомонить від стрілів. Директор Музея найшов вже дві кулі в городі та у вежі Музея. Одна куля залетіла в друкарню «Діла», коли директор Айхельберегер говорив зі мною. Гук стрілів не устає. Цієї ночі не міг я заснути. Повітря гуде від стрілів, гомонять коротко, довго, глухо або проникливо остро. Ворота домів заперті. Перед воротами поставкують цікаві діти, або женщини. Люди задержуються на кінцях вулиць, оглядаються і розходяться скоро. Ходжу спокійно. Наколи куля трафить, так на це нема ради. Об 6-тій вечером замкнені всі доми на ключ. Шиби вікон ясні від світла, бо люди не йдуть зараз спати, але гуторять. Всі уряди станули, всі склепи замкнені. Вязні вирвались силою з вязниці. Неможна купити хліба. Здається, що голод переможе обі сторони. Але це мусіло статись. Українці приневолені пійти цією дорогою, бо честь народу наказує так поступити. Поляки засліплені і закаменілі. Самі бажалиб бути на волі, але другим відмовляють права до свободи. Сервус. Здоровлю щиро і цілую тебе. Іван».

\section{Дня 5.XI.1918, вівторок, Львів}

Цілу ніч йшла стрілянина. 3 Цитаделі чути постійно скоростріл. Видно страшать, щоб поляки не йшли до приступу. Порядкую папери у себе дома, щоб був перегляд. Зайшов я до друкарні «Діла», Ринок 10. Д-р Лозинський переглядав тут рукописі і сказав до мене: «Стрільці приїхали вчора, але це вже запізно. Ворог мав час набрати відваги і зайняв важні точки. Нападає. Ще не всі стрільці прибули, лишень якась часть».

Мій пакунок з одягом і книжками заніс я до домівки «Сокола-Батька» і лишив в шафі. Всі шафи з друками і брошурами поотвирані, неначеб їх хтось нарошно розбивав.

Обід вповні український: борщ, голубці, дещо гусятини, ще 3 неділі, ціна 12 корон. Зайшов я до «Народного Дому». Привітався зі мною Гриць Коссак. Приїхав був 3.XI. Виджу оберляйтнанта Синюту та оберляйтнанта Бубелу. Надійшов редактор «Діла» Панейко. Розказав мені, що їде самоходом до Бродів. Спонукає українську кінноту, щоб прибуло сюди 200 кіннотчиків. Додадуть відваги нашим і настрашать поляків. «Як думаєте про цей наш оружний виступ?» - питає він мене, коли розповів вже про свій намір їхати до Бродів. Відповідаю йому: «Такий виступ з крісом до бою поділає на нашу смирну вдачу, на український тихий мозок. Боротьба розбуджує відвагу і рішучість. Хотяйби ця війна не скінчилась успішно, то на всякий случай буде мати вплив на наше дальше поведення. Дотепер воювали українці для других, тепер рішились ми воювати лишень для нас. Будемо інакше ставитись до ворогів і вороги зрозуміють, що посідаємо завзяття до виступу з оружжям». По лиці Панейка 
видів я, що годився зі мною, його розумне лице ясніло. Він сказав: «Напишіть таку статтю, ті думки тепер потрібні».

Пані Навроцька-Білинська і ще якась пані вносили обід до другої кімнати для старшин. 3 цієї другої кімнати вийшов Сень Горук. Вітається з приязним усміхом, змучений, невиспаний. Оповідаю, що вистава закінчена, всі образи і рисунки та різні предмети попаковані і зложені. Тепер можу взяти якусь роботу. Горук каже: «Заждіть ще. Для вас найдеться робота така, яку розумієте і добре зробите. Вона прийде. Почекайте ще». - «Нехай буде. Будьте ласкаві виписати мені тепер листок, щоб я міг одержати кріс, найрадше манліхер меншої міри, що її уживає кіннота. Він виписав листок, я попращав його і зайшов до складу оружжя. Тут привитався зі мною оберляйтнант Сивак, мій бувший ученик, дуже ввічливий і приязний в поведенню. Булак зі збірні, Цугсфірер, не міг найти малого кріса, сотник Носковський надійшов і старався найти добрий кріс. Були тут московські, мексиканські, японські кріси, всі не до ужиття. Аж Сивак, як командант цього складу, винайшов цілком новий кріс, число 3860 і видав його мені за підписом. 3 крісом на плечі і пятьма набоями пішов я Вірменською вулицею, стрінув майора Грозика в цивільнім одязі і здоровлю по військовому. Задержався, щоб я пристанув. Неспокійно глядів на мене і кліпав нервово очима. «Скажіть, що діється?» Говорю осторожно, що уважаю за потрібне, щоб не пригнобити. Не згадую навіть, що всюди якийсь нелад, як звичайно у нас.

Коло 5-тої години заходжу до урядовні «Сокола-Батька» в подвірю «Дністра». Надійшов скарбник товариства Микола Левицький. Говоримо, ми самі, ніхто не перешкаджає. Предкладає, щоб я йшов спати до нього десь там на вулицю Голомба. Він одітий цивільно, я в стрілецькім однострої з крісом. В моїм товаристві не боявся йти вулицями. Задержав нас на Личаківській вулиці український старшина з крісом на плечі, в шоломі. «Стій! - кличе до нас. - Хто йде?» - Відповідаю: «Видите, хто йде, а тут маєте мою виказку». Подаю папери. Переглядає, вкінці каже: «Знаю вас, а вас також, можете йти». Пійшов 3 нами, щоб поговорити. Розповідає так: «Був я довгий час на фронті і мене зробили четарем. Маю гарні відзначення. Маю скінчену четверту клясу. Вони знають, кого роблять шаржою». Відразу пізнати можна було хвалька. Попращали ми його. Ми в право, він дальше йшов вулицею Личаківською з чотирма вояками.

В камениці, де мешкає Микола Левицький, стрінули ми директора «Гіпотечного банку» д-ра Леся Кульчицького. Взяв моє «Діло» з рук Левицького. Я сказав йому, що все добре. Оповів нам: «Дня 3.XI. переняв я Австро-Угорський банк. В касі є два мілліони корон. Наша влада повинна перейняти ті гроші на війну».

Жена Левицького, неспокійна, подражнена, подала на стіл чай і ковбасу в платках. Говоримо до 12-тої години. Прийшов четар - медик Рижий, уймаючий в поведенню. Служив при австрійськім війську, тепер тут. Оповідає, що поляки відбили український наступ на кадетську школу, яка виглядає неначе твердиня, бо має високий мур довкола. Якесь число мертвих по нашім боці, много ранених. В городі бібліотеки Оссолінських умістили поляки скоростріл, що бє сильно на вулицю. Вікна на дахах i по пивницях дають полякам добрі криївки, щоб стріляти на вулицю. Тринчук, що я його недавно видів на вулиці Длугоша, згинув від неосторожної кулі українського вояка від «Народного дому». Німецького старшину, що мав передавати самоходи, зранила куля під час їзди вулицею. Був невдоволений боротьбою, в якій не видів ніякого пляну. У поляків бється дрібна зволоч із завзяттям молоді, яка дірвалась кріса 
і хоче ним доволі побавитись. По нашій стороні є дорослі вояки з війни в окопах, не між мурами міста. Треба було не допустити, щоб поляки загніздились денебудь.

Я переночував у Левицького.

Дня 6.XI.1918, Львів, середа

Рано о 6-тій встав я, подарував служниці одну корону на спомин, закинув кріс на плече і вертав в напрямі Ринку. Личаківською йшли гурти людей, що виглядали як онучі. Це були вояки з полону. Український склеп, де я давнійше снідав, замкнений. Придав би ся тепер. В небезпеці відчувається потреба своїх склепів і гостинниць. Оба Гриневичі переглядали вулиці. В Музею укладав я договір на винаєм галєрійки, де були зложені предмети з вистави. Директор Святицький прочитав часописі, що я ïx приніс з собою. На вулиці много людей. Якийсь пан сказав до другого: «Rozejm do godziny trzeciej». Люди піднесли голови в гору. Що такого? Над містом летів літак 3 червоним хрестом. В блиску сонця забіліли білі листки з літака, вертілись в повітрю і падали десь на дахи чи на вулицю. Товпа поспішила в тім напрямі.

Обід у Вовка без мяса: борщ, бульбяні шніцлі, сирна паляниця, голубці, ціна 15 корон. За цю ціну можна було одержати передше 15 обідів. На обід прийшов професор Посацький. Оповідав, як його напали три рабівники. Говорили по українськи, питали за виказкою, приложили револьвер до грудий і зажадали гроша. Взяли папери, калитку, годинник і сказали: «Марш!».

3 Музея забрав я карти України і заніс до книгарні ім. Шевченка. Панна Катерина Навроцька працює в книгарні. Оповідала, що в камениці, де мешкає, називають іiі «Rusinka» i викрикують на неї. Якийсь вічливий чеський старшина поміг їй вийти 3 камениці і дістатись до книгарні. Пані Панькевичева, занята також в книгарні, сказала до мене: «Люди стають неспокійні чи будуть мати що їсти. Треба би подбати, щоб був хліб в склепах для українців і для поляків».

Стрічаю д-ра Томашівського, історика у військовім платтю, як старшину. Вітаю і желаю успіху, бо довідався я, що він провадить побір. У вуйка Реваковича стрічаю буковинця Галицького. Тета Реваковичева походить також з Буковини і радо говорить про Буковину за своїх молодих часів. Дуже вічлива і дотепна, знає українську, польську, німецьку, французьку, румунську мову. Грає на пяні. Низького росту, а вуйко високий, з малою борідкою, правильними рисами лиця. Відразу відчути можна, що це розумний, поважний мущина. Тета просить, щоб приходити, як звичайно, і приносити важні новини, що діється.

Прийшла пані Матієва, жена шкільного інспектора, цілком вже сива. Це донька професора Шараневича. Я вчив ii,, бо ходила на германістику у Львові за часів професора Ришарда Маріяна Вернера. Розповідала про хліб і хлібовий листок, а також про пригоду свого мужа, якого мало що не поцілила куля. Говоримо про звіт в «Ділі», де редакція простує брехні польського звіту і виписує похвали Ількові Цьоканови, що випер з другими поляків з поєзуітського городу.

Цей звіт пишу в Музею. О 9-тій йду на вулицю Супінського, 26, до дому польської властительки, патріотки Рошковської, де винаймаю від 1908 року дві кімнати і кухню за 72 корони. Темно, стріли чути, з різних сторін. Гроші сховані в холявці. 
Дня 11.XI.1918, понеділок, Львів

В кістниці військової лічниці при Личаківській вулиці глянув я на трупи, що там лежали на тапчані $з$ дощо, що тягнувся попри довшу стіну. 3 карток, причіплених до мерців, відписав я такі написи в німецькій мові: «Ляйтнант Ліськевич помер 9.XI.1918 від ран». Мав на собі блюзу старшини від пушкоти. При другім мерці звучала картка: «Полк піхоти ч. 15. Піхотинець Грігорія Юрко Миколай, греко-східного обряду, роджений 1896, пібраний 1915, Хлімча, Буковина, помер 10.XI. Стріл в голову». Третій мерлець мав на листку напис: «Старовецький Володимир, уроджений в Знесінню, Львів, приналежний до Клепарова, уроджений 1892, греко-католик, вільного стану, прибув 6.XI. Діягноза: стріл в черево. Помер 10.XI.1918, 8:10 перед полуднем». Це три мерці з боїв за Львів. При четарі Ліськевичу не було на картці ніяких дат, коли родився, де служив, які рани спричинили його смерть.

Всі три лежать на плечах з немічно простягненими руками при тілі, очі на пів замкнені, лиця бліді, у Ліськевича голова дещо скривлена на право. Відважно перейшли через град польських куль на другий берег життя, яке з безперестанною боротьбою за лучі сонця. Не помагає ніяка туга і ніякий сум і ніяке зітхання, треба без упину старатись доглянути вчас з котрого боку грозить небезпека і поборювати ії спритом, силою, збруєю. Перемогу окуповується все жертвами. Нема перемоги без страт. Мені не було ані лячно, ані сумно на душі. Зрозумів я вже перед роками: не плачем, - не плачем, а мечем, дійти можемо до розради, за якою тужить кожне сотворіння, а це до свободи. Український нарід на власній землі не є господарем, але невільником. Неволю побороти можна лишень боротьбою з власною лінию, байдужностю, несвідомостю, безсильностю, нерішучостю, незгідливостю, служальчостю, зі смоком, який відбирає притомність і бистрість духа, а постає кільканайцять голов. Той смок спричиняє неволю народів.

Хто рветься до меча за свою свободу, у того будиться вже свідомість, уступає байдужність, зникає лінь, гине зрадлива служальчість, розвивається сила і рішучість, зрастає змисл до злуки і єдности з другими.

Говорив я не раз моїм співпрацівникам: «Злукою і боротьбою здобуває нарід свободу». Боротьбою з кожною перепоною в собі і довкола себе, злукою своїх сил, щоб навіть найдрібнійші сили лучились в одну велику силу, як пластинки снігу лучаться у великанський кругляк, що котиться непереможно і пробиває собі дорогу стрімкою полониною і високим смерековим лісом. Що значить одна мала пластинка сама? Якась мілліонова частина сили одного коня. Але пластинки злучені торощать високі ялиці і рвуть скали із собою.

Ліськевич і Грігорія і Ставровецький це пластинки, які зачинають свідомо 3 лінивої байдужности переходити в живий рух і пірвуть за собою другі пластинки українського народу, щоб промостили собі лявіною шлях до свободи на своїй землі і стерти всяку перепону і всякого противника в собі і поза собою.

Лишень боротьба, не байдужність, лишень рух, не лінь надають життю вартости і приманчивости.

Дня 13.XI.1918, середа, Львів

На вулиці Валовій стрінув мене Вітовський. Налягає дещо на ногу. На лиці якийсь заклопотаний. Випрямлююсь і дашкую на привіт. Задержується і я пристаю. 
«Перейдім до будинку намісництва, маю вам дещо сказати». Ми зайшли на перший поверх до якоїсь високої кімнати. «Сідайте, будемо говорити».

Зміст розмови був такий, щоб я обняв часопис Військового Секретаріяту, військові видання і поміг моїм досвідом, де буду міг і буду уважав за відповідне.

Дня 14.XI.1918, четвер, Львів

Під червоною плахтою з військового намету не змерз я нині в ночі. Випив каву 3 цукром, дві склянки, яку набрав я собі впрост з возової кухні на подвірю Ратуша. В друкарні «Діла» одержав я цінник, кілько буде коштувати «Правильник» та «Вістник», і пішов в намісництво. Тут предложив я Вітовському назву «Вістник Державного Секретаріяту військових справ». Вітовський бажав, щоб утворити в тім «Вістнику» додаток на інші військові справи. В кімнатах холодно. Нині прийшов вже Володимир Шухевич у військовім платтю. Проф. Лошнів приніс напис із Львом «Д. С. В. С.». В «Уставі», який зачав нині появлятись в «Українськім слові», стоїть, що гербом $\epsilon$ Лев, звернений в свій правий бік. Це значилоб, в лівий бік глядача. Однак вже много говорилось, що Лев має спинатись то в право, то в ліво, так звір стратив напрям. На мій запит не знав Вітовський нічого відповісти. Лишив Льва на мою відповідальність. Я ходив опісля до Лошніва, до його помешкання і сказав йому, щоб пустив звірюку в лівий бік, так як він це зробив, має однак нарисувати кращий щит.

Обід їмо в «Менажі» на першім поверсі: росіл, гусятина, тісточка. При обіді $\epsilon$ молодий хлопець у військовім одязі, що ходить по коритарах з малим карабіном. Я догадався, що це син Михайла Новаківського. Темні очі, тверде, прозаїчне лице. Що за характер це буде? Потомок осторожного, вирахованого, скупого чоловіка і одушевленої патріотки, яка нервово курить папірос за папіросом. Очі має темні, неначе тонь води. Якась глибина. Але яка? Кава на обід спізнилась.

Пополудні знова до намісництва. Говорю з Вітовським, щоб розпоряди випечатати поки що в дневниках. Пристає на це. На обіді був також Бубела. Підписав мені картку, щоб зайняти одну машину до писання. Савюк каже, що одну машину до писання кирилицею стягнув один семінарист. Хоче цю машину відбити. Цікавий я, чи йому це вдасться. Один розпоряд $\partial-р а$ Брика про індендантуру передав я до друку в «Ділі» і тут стрінув я сотника Скляренка, що зайшов сюди очевидно за грішми, які має дістати через Панейка з Київа. Вчора позичив у мене 30 корон.

Пополудні мерз я в своїм бюрі в Ратуші. Коли коло шестої години йти по сходах, не видно нічого. Темно. 3 долини чув я голос Людомира Огоновського, що приказував щось воякам-поліцийникам. Вечером розповідав нам в Ратуші надчетар Черевко, що говорив 3 полковником Стефановим в «Народнім Домі», і цей сказав йому, що козаки, 45 люда, пійшли були вчера ніччю з відділом добровольців здобувати Гицлівську гору. Козаки вдарили сміло, але добровольці розлетілись перед кулями машинового кріса. 3 козаків много полягло, або ранені, здається разом яких двайцять. Лінія наша від Замарстинова заняла залізничий шлях і мости. Посунулась близше, але більше нічо. Стефанів просив, щоб Черевко прийшов нині на раду. Черевко оповів, що постарався о двайцять пять плащів для гуцулів, які бються в палаті Голуховського. Там вони дуже мерзли, а нікому не впало на гадку привезти плащі, хотяй плащів при вулиці Яблоновських досхочу. Нині зловили наші щось шістьдесять полонених. Одіті по цивільному, самі вуличні пики. 
Видів я нині два авта з білими прапорцями перед домом Ставропигії, десь коло третої години по полудні. В першім авті сидів Кринжаловський і о. Сембратович, цей високий, з Америки. Решту панів в обох автах не знаю. Може поляки. Якісь переговори. Вечером говорилось, що поляки жадають триста міліціянтів своїх, а заключать мир.

Цілий день нині бють гармати із Замкової гори. Надчетар Метельський сказав: «Кожний стріл поцілив». Розумію, коли хтось стріляє з Замкової гори на Львів, мусить десь поцілити, але я йому цього не сказав. Перед вечерею роздумуємо в малім покоїку, теплім і гарно умебльованім, по директорі Островськім, що властиво робити. Требаби хиба бурити дім за домом гарматами, але передше завізвати населення, або піддатись і заказати лєгіоністам сидіти по домах, або наразитись на розбиття домів гарматами. Вечера знову на горі: клюски з мясом. Я дуже голоден від зимна і біганини. В ночі зимно, не палено, а маю много писання. Переписав я всіх пять розпорядів до «Діла», тепер пишу цей дневник. Малого Новаківського доглянув я, як вправляв крісом під проводом якогось однорочника. Знимав кріс, закладав на плече, знимав, ставив до ноги, готовив кріс до стрілу, міряв. Це було в сусідній кімнаті від мене.

В «Ділі» вичитав я, що в Німеччині запанували від 7.ХІ. соціял-демократи. Німці просять шведських, данських і голяндських соціялістів о поміч, щоб условини мира не були за строгі. Баварці оголосили себе републікою і відлучились. Це не може подобатись. Баварія пише до предсідника Америки Вільзона, що вона не спричинила вибуху війни і $є$ невинна. Це звучить несмачно. Брат чернить брата. Дня 4.XI. утворилась у Відні єврейська національна рада для цілої Австрії.

Війська вертають то з полудня, то з України, піхотою, або поїздами. На поміч полякам надїздив Ярославський полк, але його розоружено коло Стрия. Дивні і незвичайні події.

Непокоїть мене, що я опинився на бажанні Вітовського у Воєннім міністерстві. Моє місце в Міністерстві освіти. Обавляюсь, що з моєї роботи нічо не буде, як будуть мене ставити там, де не розумію роботи, як слід. Але тепер є час на війну і не на освіту. Мус воювати. Смішно, що я в одязі і в степені простого січового стрільця. Старшини в бюрі дивляться скоса. Перелякані простим вояком. Нині мав прийти директор Микола Мороз і відсвітлити машиновий кріс у вікні намісництва, але чомусь не прийшов.

Дня 15.XI.1918, пятниця, Львів

Вже десь коло дванайцятої в ночі. Хочу ще списати нинішні вражіння. Недавно, десь перед десяти мінутами гуділи гармати з Високого замку. Тепер щось тихо. Годинник ударив чверть на першу. Чую гук крісів. Власне скінчив я начерк обовязків для мого відділу у «Державнім Секретаріяті військових справ», а назвав я його «Письменничим відділом».

Я змерз в ноги. «Магазинєр» обіцяв приказати запалити, бо «в магістраті є вугля», але не припильнував цього. Зимно, сиджу в двох плащах. Гук крісів чути десь знова.

Рано, по каві пійшов я до намісництва. При каві був молоденький хорунжий в чоботах з холявами і з острогами. Десь, видно, служив в провіянтовім таборі. Тепер не їде на коні, ані на возі. Пощо йому острогів? Командант залоги магістрату також з острогами і в високих жовтих чоботах. Харчовий Метельський також з острогами. Всі опинились $з$ поля на бруці.

При передачі мого звіту сказав мені Вітовський: «Перемишль упав». Ляхи здобули його для себе. Але як? Чи мали також мійське шумовиння за собою, яке не 
має що тратити, а може убивати і рабувати? Прийшов Яцура в шоломі і з крісом та величезних очицях. Виглядає як мала, низонька, широка твердиня. Він заніс опісля скриньку з плитами від сторожихи при вул. Чарнецького, 24 до Ратуша. В середині є 120 плит, папер і хемікалія.

Обід був пізно. Дівчата варили десь на другім поверсі і зносили: росіл, м’ясо 3 бульбою. Я дістав подвійний росіл, але це все за мало. Зимно, ходити треба много. В ночі змерз я порядно і ставав щось три рази на малу сторону. А виходок далеко, цівки видно попсулись і там повстала одна велика калюжа. Світла нема, бо вже газовня не працює. Є надія, що також елєктрика перестане йти і вугля не стане. Тоді стане темно і буде добре взаїмно себе різати. В день не видно надчетаря Черевка, мав пійти здобувати кадетську школу. Четар Бабяк взяв кріс через плече і зник також. Яцура прийшов по обіді і ми пішли до шпиталю. Це військовий шпиталь на Личакові. Ми найшли чоловіка, що відповідав за трупи. «Є в трупарні поляглі вояки?» Трупар відповідає: «Були. Що день їх є по шість до вісім». «Як називались?»- «Не мали картки. Незнані вояки, але з цих боїв. Коло третої години по полудні шлю їх щодня на цвинтар». Пійшов я до бюра в намісництві. Між паперами в одній кімнаті найшов я брошуру великого урядового формату про устрій Міністерства війни у Відні. Переглянув я деякі розділи і найшов замітки, які були практичні. Я переробив зараз мій власний начерк для Письменничого відділу. Панчак щось там пише при своїм бюрку. Помагає йому панночка, моя бувша учениця. Інші «референти» щось дудрають по своїх столиках. Так і видно, що не мають за що взятись. Гарасимович прийшов вечером. Бубела сказав йому, щоб інтендатура переймала чим скорше майно по австрійській державі, бо все розкрадають. Мілліярди зникають між товпою. Я зауважив: «Хтось повинен автом обїхати головні склади, наставити варти, подавати повновласти, заки всього не розграблять». Холодно в бюрах намісництва і по високих коритарах. Я змерз. Вояки в сусідній кімнаті, що поставили на вікно машиновий кріс, співають пісню за піснею. Українці дійсно співучий нарід. В яких хвилях вони співають? Я відходив і лишив у них ключі від бюр секретаріяту. Веселі.

На вечерю пироги і кава, але я голоден. Яцура прийшов знову, але тепер вже не 3 крісом, лишень з гранатою. Видно, бавить його, що може страшно збройно виглядати. Носить тяжку гранату з залізною, кулистою головкою. Рано ще оповідав мені, що чоботи стягнув з ляха, якого забив при наступі коло Перзенківки. Показує плити із знимок на Великій Україні.

Сотник Скляренко показував мені вдень перепустку, що їде автом на Україну по панцирний самохід. Чи дійсно? Може це лишень спосіб, щоб забратись зі Львова, жінку вивезти, а опісля не вернути і нічого не прислати? Коло десятої години перед полуднем його жена щось викрикувала, вбігала то вибігала з кімнати. Скляренко вибігав за нею. Савюк сказав мені, що жінка злобиться на сотника Скляренка і нині кричала на нього: «Йоб твою мать, чорт би тя побрал». Савюка це дивувало. «Як ми не знаємо жінок, коли нежонаті. Сліпі котята! Мущини пізно стають видючими». Відповідаю: «Цеж жіночий спосіб ведення. Кричить, верещить, не знати по що. Кусає криком».

Коли це пишу, чути по коритарах кроки, грюк отвираних і замиканих дверей. Боюсь йти спати, бо спю на підлозі, а там зимно і твердо. Нині перший день 3 добрим морозом і з снігом. Війна ще не кінчиться. В «Ділі» випечатані нині розпоряди «Військового секретаріяту» ч. 1-5. Присяга для українських військ, перейма майна давної держави на власність Західно-Української Народної Републіки, поділ на области 
Львів, Станиславів, Тернопіль, поклик до війська, приказ для окружних командантів. Це перші розпоряди. Я написав в заголовку «Розпорядження», М. Возняк в «Ділі» поправив на «Розпорядки», а після мене повинно бути «Розпоряди».

Десь грюкають стріли.

Дня 16.XI.1918, субота, Львів

Студінь. В ночі треба вставати і бігати на малу сторону до виходка, де тихо стоїть вонюче озеро. Не пю кави на снідання, хочу їсти лишень хліб, який має мені видати капраль Гера, але його нема в «Портієрці». Він повиненби бути в подвірю Ратуша за вікном з кратами, але його там нема. Приносить мені хліб одна 3 пань, що йде по нього на перший поверх. Дякую і подивляю непорядок. Вирвався мені ремінець при «штильпах». Савюк веде мене на мою просьбу до «шустерні». Під час коли оден 3 шевців пришиває мені ремінець, приходить одна 3 панночок, що тут варять їсти. Каже: «Дайте мені чорної пасти». - «Не маємо». - «Алеж де?» - «Маємо лишень жовту». - «Що, і ви не маєте?» - Каже, звернена до середного, і відходить. Коли замкнулись двері, відзивається середний: «Щітки дай, гребеня дай, пасти дай, нитки дай». Крайній від вікна: «Але коби лишень принесли назад». Крайний від дверей скінчив шити, я заложив «штильпу»: «Дякую, гаразд».

В намісництві передав я начерк Письменничого відділу по довгім чеканню, бо в кімнаті Бубели, що творить передпокій до кімнати секретаря Вітовського, пригатилось много людий, які хотіли поговорити в ріжних справах. Є і Біляч з Перемишля. Оповідає, що Перемишль упав, бо поляки мали чотири гармати, мужва билась, але старшини недописали. Чи все це правда? Виглядає на теревені. Паліїв передав мені до перегляду і поправи нарис про платню для війська. Писав якийсь фельдвебель, бридко, з похибками, бо капітан Снджейовський, який відповідає за цей нарис, уважав за пониження, щоб переписав це в приличній формі. Переписування понижає капітана навіть тоді, як нема нікого, що порядно пише. А може сам капітан на воєнній стопі 3 письмом? Вітовський дав мені до часописів нарис про судівництво для війська. Я спіткав на вулиці Антона Лотоцького і переписав з ним розпоряд два рази, щоб був текст для «Діла» і для «Слова». 3 Лотоцьким перейшов я до Народного Дому, чи дадуть йому одяг, щоб порядно виглядав, бо хотівби я його взяти до свого відділу. Маємо заглянути ще раз сюди о 4-тій.

На обід борщ і шницель з бульбою та сім сухарців. Їм сам на своїм чорноскірім столі в бюрі, де є два столи, телєфонічна клітка та три шафи з паперами. Командант їсть у своїй спальні разом з двома старшинами, зрештою їсть кожний у своїм куті. Харчовий надчетар Метельський осібно, хорунжий Голубець осібно, малий Новаківський їсть в малій настроєвій кімнатці директора Островського.

Йду з Яцурою, що двигає кріс і камеру до шпиталя, але нині нема ані одного трупа з боїв. Світлимо по дорозі синьо-жовтий прапор на намісництві, входимо на другий поверх і світлимо машиновий кріс у вікні. Командант скоростріла, «Цугсфірер», каже до мене: «Вже пять літ служу коло машінгвера. Знаю з ним обходитись. Умію розібрати і зложити, навіть як би мене хто вночі збудив». Вояк, що сів собі на вікно коло цівки, має гранату в руках, а також кирпатий ніс над ротом, який псує нам дещо знимку.

Коли це пишу, бє дванайцята година. Якась тихша ніч, стрілів не чути много i мало кроків в коритарі Ратуша. Видно менше людий тут нині. Кухня на другім поверсі, 
вже вчера тамки перенеслася. Але тепер чую гарматний стріл, знов стріл, знов стріл, стріл... Пушкарі гріють Львів, бо мороз на дворі. Стріл, стріл, стріл...

О 4-тій годині по полудні прийшов Лотоцький і ми оба пійшли до Народного Дому Краківською вулицею. У великій салі повно людий. Стоять, входять, виходять, пишуть при столиках. Прошу надчетаря Терлецького, щоб видав все в добрім стані, бож це для співробітника у Військовім Секретаріяті. Коли ми вертали, пояснив я Лотоцькому, щоб одягнувся як слід, бо мусить добре виглядати. Шапка його і одяг військові, але занедбані, черевики і камаші також. Пійшов я до намісництва і переглядаю «Діло», щоб зібрати випечатані вже розпоряди до «Вістника» Секретаріяту. Читав я до 8-мої. Панчак пішов до Народного Дому, до Горука, по ріжні поради. Я глянув на столики референтів. Двох референтів чекає на ліпший час, це Стафіняк до демобілізації і Чапельський до залізниць. Як возити сіно, коли ще не скошене, бо росте. Місяць освічує пусті вулиці. Кличу на розі Ринку «Свій». Вартовий перепускає. В Ратуші спокійно. Може мало людий? Заблукую на галєрію великої салі засідань. Заходив я тут прислухуватись промовам радних. Лямпи на павуках блимають притемнені. По обох довгих боках салі на сінниках сплять наші вояки. Мусять відпочити. Польонія на великім образі Стики показує на них рукою. Міцкевич, Костюшко, Гловацький, різні польські провідники виглядають занепокоєні, не можуть спати, стоять напружені: «Ukrainski chłop tutaj». В кухні щось пять панночок, світяться парафінові свічки. Дістаю на вечерю яєчницю, каву з молоком і хліб. Не відчуваю, що я заспокоїв голод по цілодневній біганині. Панночки говорять про свої журби. Тепер кожний їсть осібно. Бігати треба з підносами на другий поверх, а відти розносити їду. Місто шіснайцять шницлів треба було видати нині трийцять - не знати властиво, кілько є осіб. Мусять робити більше, як лишень хтось зажадає. Панночка, котрій я одного разу сказав: «Що це за порядок?», каже: «Мені прикро, коли почую який докір. Я не можу сказати, що нема вже більше обідів». Відповідаю: «Досвід навчить не робити собі нічо з докорів, коли не можна роботи ліпше виконати». Вона каже: «Ми не раз мусимо в ночі ставати і варити, колись тут для Черевка». Одна оповідала пригоду, що мала їй трафитись: «Ми йшли вулицею Академічною до Народного Дому. Я і медик Шкондеюк. Він був по цивільному одітий і ніс револьвер в руці, щоб зараз стріляти. Двох ляхів, я би зараз одного з них пізнала, приступило до нього: «Ręce w góre». Відобрали йому револьвер і застрілили його його власним револьвером. А близько цього місця, зараз коло рогу готелю Жоржа, застрілили також одного стрільця. Це нещасливе місце». Я слухав і ледви моїм ухам вірив. «Магазинєр», що обіцяв казати напалити в моїй кімнатці, оповідав: «Поляки обстрілюють машиновим крісом Жовківську рогачку. Я їхав по харчі, бо харчі можна дістати лишень з Підзамча. Кулі перейшли мені через рукави, візникови також. Кріс вимірений на рампу. Як ми вертались, треба було сховатись за віз і скоро їхати. Вже раз убили мені там коня. Цей кінь все ще там лежить». - «Що то буде, як вугля не стане?» - Каже одна $з$ панночок. - «Свічок нема, от і ця догоряє».

Ми йшли в діл. Я сів в неопаленій все ще кімнатці і читав впоряд, щоб приготовити його до друку. Тепер списую ці вражіння. Зимно мені в пальці рук і в ноги. Чути стуканину крісів, зрештою тихо. Жарівки не горять вже в передпокою. Скляренко поїхав по панцирне авто, може і по гроші для себе. Жінки його, підмальованої, я нині не бачив. На годиннику 12.30. Перепустки з друкарні передав я нині жандармерії. Індишевський і Шипайло зойкали, що дорогі, 400 перепусток коштує 100 корон, папір і друк. 
Мушу це записати: нині прийшов до нас, в намісництво, Гужковський. Хотів дістати коні до Винник. Його жінка десь поза Львовом. Він журиться, що з нею. Говорить про неї і каже нагло: «Але архикнязя, так якби всі забули. Він в Станіславові. Нехай би служив в українським війську, як вже посвятився українцям». Відповідаю: «Тепер всі журимося війною у Львові, браком гроша і хліба, пане бароне». Він на це тикає мені, хотяй перший раз в життю говорить до мене: «Будь так добрий, щоб я видівся з Бубелою. Я мешкаю Панська, 27». Я кажу: «Він буде тут завтра в часі від 8.30 до 10-тої. Колиб нині прийшов, так я зголошу йому». Я зголосив Бубелі, але він відповів: «Чи я мав би до нього ходити?» Відповідаю: «Не берусь рішати, хіба колиб Ви тамтуди переходили». - Гужковський із своїм поважним, приязним лицем і спокійними рухами виглядав мені занедбаний і заклопотаний. В військовім платтю і в довгім чорнім плащі.

Дня 17.XI.1918, неділя, Львів

В ночі зимно на підлозі спати. Я скулився в четверо, щоб не замерзнути, встав захриплий, з болем голови, голоден, голоден. Кави не пив я, бракувало мені до цього рішучости, взяв я лишень один бохонець хліба через крати на два дні, зїв скірку, сховав мякушку в шуфляду і вийшов.

По дорозі в намісництво вступив я до Волоської церкви змовити «Отченаш». Фридрих Великий сказав: «Бог держав все з міцними раменами». Але тепер не знати відки взяти міцнійший регімент.

Купую німецький часопис «Lemberger-Zeitung». В Німеччині запанували скрізь соціялісти. Австрійські німці хотять прилучитись до Німеччини, Форарльберг до Швайцарії, чехи увійшли в словацьку часть Мадярщини. Подана була цікава подробиця: австрійська армія рушила від ріки Піяви, але щоб демобілізація поступала поволи, австрійські полководці попросили італійців, щоб зайшли австрійську армію 3 переду і здержували в поході. Полки пускаються буквально впоперек піль, щоб зайти домів. Оповідали мені старшини тут в залозі, що через злу їду і брак найпотребнійших річий стратили вояки поважаннє перед офіцирами. Офіцири звали цей відрух вояків большевизмом.

В намісництві рисував Лотоцький перед полуднем рубрики, о годині пів до десятої відбулась присяга. Щось вісімнайцять люда стало півколесом, на обох краях Бубела і я. Вітовський провів українську присягу і сказав, що ми перші присягаємо на цю присягу.

На обід в Ратуші, куди я належу, юшка, м'ясо з морквою, сухарці з капустою. Сотникова Скляренкова просила мене о хліб. Я сказав паням, щоб про неї не забували і старались для неї о хліб та о страву. Мужа нема, а жінка без мужа звичайно немічна, як хміль без підпори. 3 Яцурою відсвітлили ми два трупи в трупарні військового шпиталя. Один якийсь 3 дуже звичайним лицем, а другий з спокійними чертами цугсфірер від артилєрії, Тимошецький, здається, звався. Закінчив світову війну смертю за Україну. Не дістався домів, поліг за своїх. Я дав обом трупарям по короні, тому Розумному і його помічникові, оба говорили по українськи.

Лікар поляк, що зачіпив мене одного разу в центральній каварні, заговорив до мене в городі по українськи, що має много роботи. Кожний робиться приємний і не знає, як збути свою чемність при зміні порядку.

Ми оба вертали Личаківською вулицею. Два великі міномети їхали в долину. Вояки йшли попри коні. 3 заду надігнав мене Мачуга, знакомий мені через Гаруха 
Юліяна. Йшов з крісом. Оповів поспішно, що приїхав І-шого, брав участь в Гуцульській сотні у всіх боях. Я скрутив на право до намісництва, Яцура на ліво до знакомих по добрий світлинний прилад.

Паліїв хоче мати відозву про мобілізацію і літографовану відбитку про платню. Панчак оповідає, що Стефанів не запровадив порядку. Велику ролю серед його старшин грає цинік Синюта і бездушний Гузар. Не дібрав людей, не розмістив їх, як належить. «3 поляками, - сказав, - «буде перемиря 48 годин. Може прийде до мира, але можливо до дальших боїв».

На вечерю треба чекати. За цей час четар, що має провід на вулиці Казимірівській, в поліційнім будинку, оповідає, як наші вояки з села набрали в склепі горівок, солонини, як знов десь рознесли склеп 3 полотном, блюзами і пакували до наплечників. Львівські «батяри» стріляють. Гониться за ними а їх не можна відкрити. Нема їх, лишились лишень по них консерви, мармеляди, оріхи, патрони. Знають камениці, людність їх криє і вони можуть сховатись добре. Тяжко їх вигубити. Нині мав четар «большовицьку» раду із вояками-селянами, щоб зарадити тому, що втікають домів. Нехай пильнують себе самі. Як може Українська держава вирости, як вони іiі лишуть без своєї опіки? Вояки, вже старші люди, рішились лишити, а щодо горівок і іншої добичі зложили виділ, який має цего добра пильнувати. Пити будуть, як все скінчиться. Одноголосна ухвала. «Jontek, powieś się w powietrzu, bo tu zle». Кличе «батяр» до «батяра», коли українці добре стріляють. На вулиці дуже легко згинути, бо з брами або з вікна паде стріл і чоловік пропав. Старшини розповідали про Сербію та Італію. Як серби не люблять «шваба», а як італійці зжились 3 нашими людьми. Баварці добрий нарід, але прусаки горді і розумні. Всьо роблять систематично, вираховано, після пляну. Рабують пляново, не розбивають. Наш сват стрілив до бочки, зробив діру, щоб набрати собі трохи вина, а тисячі літрів витекло на землю. Німець заладував бочки з вином і вивіз до Німеччини.

Вечеря. Пироги з капустою і пересолені скварки. Длятого смакує до скварків $\mathrm{i}$ хліба пиво. Я голоден і зимно. Їм як вовк і дальше голоден і змучений. Але від їди зробилось тепло. Очі клеяться, бо цілий день думаю, пишу, ходжу, слухаю, говорю, відповідаю, а також зле сплю, бо на твердій землі і зриватись мушу. Командант не має охоти казати висушити пахуче озеро перед виходками. Метельський обіцяє при вечері, що зробить комашню, коли скінчиться львівська війна. В пивниці відкрили десь магістратське вино. Пивниця замкнена, так вино не витече. Він її тоді отворить, каже зарізати дві свині. Буде що їсти. Скрізь практичний і розумний чоловік. Приємно слухати. Вже пів до дванайцятої. Нині мушу скорше йти спати. Якість стріли. Інжинєр Гушалевич дав свій прилад з сочкою Фойгтлєндера, щоб Яцура робив ним знимки.

\section{Дня 18.XI.1918, понеділок, Львів}

Вечером, около 10-тої години сиджу в кімнатці з телєфонічною шафою і печатками львівського магістрату. Огонь горить в печі. Хлопець Іван Фліщак запалив на приказ магазинєра Дзеровича. Прецінь раз. Вже обіцював кілька разів. А в послідних днях я перестудився, кашляю і в гортанці коле. Вчера положився я спати перший раз в цій кімнаті на підлозі. Підстелив комісьний плащ, а вкрився своїм власним плащем і хідником, але лишився в одінню, хотяй стягнув черевики. Боявся перестуди, бо не можна порядно вкритися. Рано встав я десь о 7-мій, випив дві склянки чаю в кімнатці, де мешкає дверник на долині, і пійшов до друкарні обговорити і замовити великий 
афіш та виказку для вояків. Сказали мені, що корректу можна зробити о 11.30. Я пійшов до бюра в намісництві. Лотоцький мучився над рубриками для індендантури. «Lemberger-Zeitung» коштує 50 сотиків у підростків, що її приносять 3 вулиці Сапіги, це є 3 «Польщі», як звуть простір, обсаджений поляками. Дивачні вісти: цісар Карло інтернований в Шенбруні, не вспів переїхати до Геделлє на Угорщині. Цісар Вільгельм десь утік, не знати куди, зник, може, на котрийсь 3 його замків. Подані новинки про мниме вбивство Клєманса і німецького наслідника престола. Тепер всякі вісти можливі.

На поправу в друкарні мусив я чекати. Виказку зложив якийсь недолугий складач зле. Цілий текст казав я змінити.

На обід росіл з макароном, мясо з бульбою і капустою, без смаку, бо без ніякої заправи. До того горнятко кави. Я був ситий і не боявся зимна і перестуди.

3 Яцурою пішов я до шпиталю, щоб улекшити йому і сказати, що має зробити. Він відсвітлив приладом інжинєра Гушалевича, сочкою Фойгтлєндера, убитого нашого вояка, на котрого картці прочитав я записку: «І. полк князя Льва. Машталір Михайло, батько Стах Машталір, село Черепень, Львів, згинув 13.XI.1918». Мав лице закровавлене. Я попросив трупара, розумного в розмові чоловіка, щоби йому обтер вогкою шматою лице. Він це зробив. Мене здивував шляхотний, орлиний профіль цього вояка-селянина. Назва дивна: Машталір. Бог зна, відки його предки заблукали між українські селяни. А ось тепер згинув за українську сорочку, що мав іiі з вишиваним ковніром на собі. Поруч нього лежала жінка, що вмерла в гарнізоновім шпиталі, а поруч жінки майже нагий хлопиця, що помер пробитий при рабованю нашим вартовим. Я виліз на поміст, де лежали трупи, і глянув йому в лице й отверті губи. Звичайне, просте, мазуровате лице, поражаючо зухвалий, малий ніс.

3 військового шпиталю пішов я назад до бюра в намісництві. Вислав Лотоцького до коректи афіша, а сам писав платні вояцтву в рубрики. Перед тим зайшов я о 3.30 до Вітовського, щоб йому предложити цілий афіш до одобрення і зголосити прийом Лотоцького до служби у моїм відділі. Предложив я йому до затвердження слова присяги для української жандармерії і поправку вступних слів вояцької присяги.

Віддав я привіт військовому і глянув в цій хвилі на його ковнір. Нині мав вже пришиті три золоті звіздки на срібнім ковнірі... Полковник. Так само, як Стефанів. Гриць Коссак має також три золоті звізди на срібнім полі. Гриць Коссак мав впрост зажадати цего степеня від Національної ради. Виділи, що мусять пристати на його домагання.

Вітовський вічливий в поведенню. Спокійно говорить, до річи, має м'ягкий голос і дуже гарні очі. А з вічми стрічається кожний.

Викінчив я тоті обридливі рубрики з платнею. Нудно писати, але кожний цікавий на них, що дістане за свою роботу. Платня для боєвиків у Львові більша як звичайно в полі, щоб задержати тут людий в небезпечнім бою.

Десь коло 7-мої години прийшов широкоплечий, круглий військовий духовник в кімнату Панчака і питав про панночку, що пише у відділі Панчака, за братом і женою. Я просив його сідати. Оповідав, що вертає власне з 36-тим полком 3-над ріки Піяви в Італії. Мали бій ще 30-го жовтня, потім відступали. В Краіні розоружили їх мадяри до штанів і блюзи безпощадно, під загрозою застрілу. Мадяри мали збрую, а вони не мали в руках нічого. В Мункачі много вояків лишилось, бо не стало місця в поїзді. В Стрию розбрелись рештки. Много вояків вимерло в Італії на малярію. Так вмирає велика держава. 
Пішов я до ратуша, де є моя кватира. На вечеру клюски якоюсь мармелядою. Вояки від харчовання роздобули десь троха меду. Хто служить при харчованню, вміє шукати і находити. Але мід без ніякого смаку.

Прийшов Кринжаловський до ратуша. Питався за Мартинцем. Я запровадив його. Кринжаловський держиться з гори. Старається мене ігнорувати. Коли б він знав, як мені байдужні такі міни. Це викликає гумор, веселійше потім думати і лекше працювати.

Академічної гімназії, Вассіяна. Його письменні задачі мусив я кілька разів читати, щоб їх розуміти. Вбився мені в память. Приїхав з Бродів і оповів мені на мої запити, що там в Бродах є старшини, але всі не енергічні. Я сказав йому на це: «їдять і їли лишень бульбу і капусту. Це відбилось на них». Він усміхнувся і сказав: «Це правда, бульбяна енергія». Коли виходив, сказав я до нього: «Остерігайте українців перед бульбою».

До Мартинця прийшли інші старшини, між ними якийсь в жупані з червоним поясом. Видно, з-над Дніпра. Він сказав: «Нема тут москалів. Тут було б ще много порабувати». I показав рукою по стінах, де висіли портрети в золотистих рамах, занавіси, образи. По кімнатах лежали хідники, стояли гарні крісла, столи, софи. Бюра львівського магістрату добре виглядають.

Савюк нишпорив в гарній шафі з паперами і знайшов рукописі якогось ляйтнанта Benesch-Benau з міста Reichenberg, Strassauer-Strasse, № 18. Натрафив на його драму, написану в німецькій мові на писальній машині, дневник, записник із стихами, якусь жіночу рукавичку, хустинку, обшиту коронкою, від котрої заносило ще пахощами, много видівок та листів. Кажу до Савяка: «Спакуйте, обвяжіть і напишіть на верху його адресу, щоб вернуло до нього. А може, вже не жиє? Рукопис це цінна річ, хто знищить чужий рукопис, то так неначе б спалив його дім». Вкінці я сам позбирав витягнені рукописи, письма, хусточку і рукавичку, звязав і положив назад до шафи посадника Львова. Колись дістануться ці спомини до рук, для котрих вони є скарбом.

Треба кластися спати. А це штука. Вправді в кімнатці дещо напалено, але підлога тверда, нема чим вкритись, а груди дальше хрипають.

Завішення оружжя зачалось нині о 6-тій рано. Четар, що дає провід воякам на Казимирській вулиці, в будинку, де урядує поліція, оповідав много про батярів, що бються по стороні поляків і все заганяються рабувати жидів. Розбивають для розривки жидівські склепи.

В шпиталі говорив я із стрільцем, раненим коло Кадетської школи. Оповідав, що поляків було там до 200, та що удалось їм пхнути українців взад.

До ратуша приходив нині вечером стрілець від артилєрії. Із замку стріляє наша артилєрія на кадетську школу і на дворець. Не раз 150 стрілів денно.

Дня 19.XI.1918, вівторок, Львів

Знова вечір в зимній кімнаті з актами в шафках, з гачками на ключики, з таблицею, на котрій виписані урядники магістрату. Власне запалив в печі хлопчисько, той самий, що це вже вчора робив. Питаюсь: «Як Ви давно тут?» - «А від часу, як втік 3 поліції». - «3 котрої?» - «А вот з вулиці Баторого». - «Що ж Ви там робили?» - «Та бо знаєте, я знаю шевство, бо мій тато швець і дав мене на один рік до жида на науку». - «А щож, чи то не замало?» - «Буде 3 мене». - «Як хтось довше вчиться, то ліпше вміє. Варта добре вміти, то чоботи не будуть ні замалі, ні завеликі і давити 
не будуть». - «Я беру міру папером, бо читати не вмію, роблю значки на папері і знаю, яка велика нога. Найважнійше набити на добре копито». - «Що ж Ви робили на поліції?» - «Та я в жида викраяв скіру з повоза. Жид прийшов до мене дати собі прищіпку, тай побачив у мене кусень скіри. Тай каже: «А відки ти се маєш?» - А й кажу: «Я в трені дістав». - «А се моя шкіра з повоза», - каже жид. Заплатив за прищіпку, а потім прийшов з шандаром. Тай мене заарештували і я дістав три місяці».

Думаю собі: гарне товариство тут в ратуші. «А довго Ви тут?», - питаю. - «Та вже щось три тижні. Я втік з арешту із злодіями». - «Якжеж це було? То цікаве, оповіджте». - «Ми втекли з арешту». - «Але відки Ви знали, що йде українське військо?»- «Бо стріляли». - «Але то могли інші стріляти». - «Бо вахмайстри були сумні, забрали палаші і вийшли. Навіть застемпця втік». - «Але як Ви отворили двері?» - «От там були моцні хлопи, лавкою розбили двері, скобель вилетів і колодка злетіла. Вони колодкою розбили другі колодки. Колодка була велика, як Ваша шапка. Перше втікли з третого поверху, а потім пійшли в долину і порозбивали». - «А з подвіря як?» - «Через мур. Штахети виломили і приставили». - «Але по другім боці?» - «Зіскочили». - «Ніхто ноги не зломив?» - «Але бо, ніхто. Українці нас гвером затримали, поставили до гліду і потайлювали до роботи. Так я прийшов до ратуша, до кухні, начиння мити. Але завтра замельдуюся до оберляйтнанта, що йду до дому». - «Та чого? Та витримайте ще $з о$ два тижні. Прецінь тут Вам добре». - «Та добре. Добре дають їсти, але дома то я мав парене молоко, масло, сир приносили, щоби я скоро робив черевики, то я мав другий підбородок, а тут я худий». Потім диктував мені лист до своєї мами: «Каська Чорній, Мости Великі, Вовча вулиця, за цвинтарем ч. 225». Нічо не знав, що довкола діється, пощо війна. Був з кухні і мив. Хотів тепер до мами пити молоко і дістати другий підбородок.

Пізнійше прийшов другий, який помагав в печах палити. Питаюсь, чи його село далеко. «Я з Білки». - «Шляхоцька?» - «Ні. Крулєвска». - «Якжеж довго Ви у Львові?» - «Три місяці сидів я тут в криміналі інквізитом, бо війт сказав, що я вікна вибив, хотяй не мав на це свідків і мене були не засудили». - «А вмієте читати, писати?» - «Вмію, я ходив до школи. Тамтой не вміє, на праве око сліпий і не міг йти до війська, хотяй 21-літний». - «А добре Вам тут тепер?» - «Я до дому не пійду, мені тут добре. Ми в гарешті не діставали їсти. На снідання якусь юшку з бульби, на обід якусь чорну капусту, на вечерю знов юшку. Гріх так людей мучити. Як ми втікли, то ми були голодні. Ми втікли в неділю пополудні. Кричали: «Puszczaj. Nasze wojsko je». Потім втікли через браму. Ми прийшли до ратуша, дали нам хліба і доброї юшки. Ми наїлися порядно. Нам говорили: «Не бійтесь. Вам нічого не станесь. Ми дістали всяку

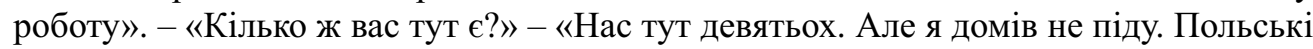
лєгіони піддадуться. Вони не мають що їсти. У них лиця такі: - «показує пальцями, які втискає в оба лиця» - «То їм відхочеться Польськи. Наша фана на ратуші». «Naco nam Polski, nam się jesc chce». Він поправив в печі вуголь і пішов. В печі шумить.

Мій правильник до «впоряду» зник мені. Очевидно хтось забрав для себе. Референт Міністерства лишився без правильника. А тут треба приготовити прикази до друку, щоб виграти війну. Просив я Яцуру, щоб найшов мені впоряд у когось на шість днів. Може, виратує військо. Хто взяв? Чи якийсь полководець, чи простак?

Яцура світлив нині гурт машинового кріса. Четар Бабяк просив, щоб відсвітлити групу ще раз з одним десятником. Я уставляв також старшинський збір. Голубця бракувало. 
На вечерю клюски з капустою без омасти. Шерстиняк, що із старшого стрільця вийшов вже на десятника, поясняв мені, що омасту панночки не дістали. Десь поділась, як мій правильник. Нині перейняв Бабяк харч замість Метельського і пояснив, що офіцери будуть їли, як передше в столовій, а однорочняки в салі президента 3 портретами.

3 крісом через плече перейшов я по обіді до музею при вулиці Мохнацького по ковнірець і сорочку, бо білля було вже брудне. Від стрілецької вистави в жовтні лишились там мої речі. Донька сторожихи пришила мені гузик до плаща, який я найшов в кишені. Коли гузик був пришитий, доглянув я, що він також був лискучий, але мав дещо відмінний крій, як другі гузики, що держались ще плаща. Видно, що я підняв не мій гузик, але якоїсь другої армії. Коли я йшов Академічною вулицею, салютував я до кріса Галущинському, що переходив попри мене. Він усміхнувся своїм знаним ввічливим усміхом. Люди проходжуються свобіднійше, бо завішення оружжя. Коли йде бій, вулиці порожні.

На снідання одержав я білу каву. Нині дістав я два бохонця хліба. Незнаю, чому два, а не оден. На обід юшка, мясо з бульбою, макаран з яблоками. Виглядає на празник, але пайки малі. Друкарня виготовила вже афіш з розпорядами два, три, чотири, і зелені виказки для вояків. Рожейовський приніс тексти про «Суротати» (nідлітки) до переписання в намісництві. Підчас коли Панчак і його писарка їли свою вечерю, оповідав їм Паліїв про ніч з дня 31-го жовтня на 1-ий падолист. На нараді розділено роботу. Треба було зайняти касарні і важні уряди. Всі важні точки обсадити українцями. Оповідав поверхово. Він много причинився до успіху. Виглядає на совісного і доброго робітника, який виконає це, до чого візметься.

Дня 20.ХІ.1918, середа, Львів

Прийшов я власне 3 кіна. Німці-вояки від радіо-телєграфічної групи зайшли в магістраті кіновий прилад до цензури фільмів марки Pathe freres в Парижі. Вони давали вже кілька разів представлення в кімнатах магістрату. Я пійшов на це доперва нині з Яцурою. Самі веселі сценки. Стояв я в кімнаті, де був прилад. Вояк, що крутив, очевидно фаховець, звивався спритно і безпечно. Знав докладно, що треба робити. Я задержався лишень через три сценки, бо шкода часу. Хочу описати в своїм дневнику нинішний день спокою.

Нині купив я числа «Діла» від 15.Х. до 20.Х.1918.

\section{Дня 21.XI.1918, четвер, Львів}

Неспокійні вісти. Поляки дістали якусь поміч, що йде зі сторони Личакова i Зеленої вулиці. Хто це провірив? Хто побачив і в який спосіб? Видно, українські стійки.

Хтось приніс вістку з Народного Дому, що маємо вибратись із Львова. Перед полуднем стрінув я архікнязя Вільгельма Вишиваного в сінях військової команди при вулиці Чарнецького. Високого росту, около 30 літний, уймаючого лиця, говорив спокійно кілька слів зі мною. Пополудні пакував я папери в бюрі, в будинку намісництва. Кріс, який я дістав вже передше для Антона Лотоцького, вложив я за шафу, чому, не знаю. Лотоцького не було, де мешкає, не знаю. 3 дверей не зняв я ані напису «Державний Секретаріят Військових Справ», ні Льва, що його рисував професор Лошнів. Забрав я всі числа «Діла» з послідних тижнів, мої записки, рукописі, чистий папір, чорнило, ручку, пера, олівці. Пакунок не був великий. Десь коло 12-тої в ночі 
рушили ми з ратуша. Мій пакунок положив я на віз і з крісом в руках йшов за возом Жовківською вулицею. Ми переїздили через телєграфічні дроти, що лежали пірвані впоперек дороги, і їхали поволі годинами.

Джерело: ЦДАВО України. Ф. 4379. Оп. 1. Спр. 21. Арк. 37-55; Боберський I. Дневник 15.IX.1918-22.V.1919. Арк. 37-55. Осередок української культури і освіти у Вінніпезі.

\section{REFERENCES}

1. Boberskyi, I. (2003). Shchodennyk, 1918-1919 rr. (Yu. A. Mytsyk, Comp.). Kyiv: Vyd. dim «KM Akademiia» [in Ukrainian].

2. Diedyk, O. (2018). Boi u Lvovi. 1-21 lystopada 1918 roku (Pt. 1). Lviv: Vyd-vo «Astroliabiia» [in Ukrainian].

3. Dilo. (1918, Veresen 20), 214 (9774), 4 [in Ukrainian].

4. Dilo. (1918, Zhovten 16), 235 (9795), 4 [in Ukrainian].

5. Dilo. (1918, Zhovten 31), 248 (9808), 3 [in Ukrainian].

6. Lysyi, Yu., \& Ilkiv-Svydnytskyi, M. (Comps.). (2018). Zakhidno-Ukrainska Narodna Respublika v dokumentakh i materialakh Naukovoi biblioteky Lvivskoho natsionalnoho universytetu imeni Ivana Franka: albom-kataloh. Lviv [in Ukrainian].

7. Rozporiadky Derzhavnoho Sekretariiatu Viiskovykh sprav z dnia 13 padolysta 1918. (1918, Lystopad 16). Dilo, 263 (9823), 1-2 [in Ukrainian].

8. Sova, A. (2014). Viiskovo-politychna diialnist Ivana Boberskoho v roky Pershoi svitovoi viiny. Humanitarni dystsypliny u navchalno-vykhovnomu protsesi vyshchykh navchalnykh zakladiv: zb. nauk. statei, 4, 90-100 [in Ukrainian].

9. Sova, A. (2019). Diialnist Ivana Boberskoho yak povnovazhnoho predstavnyka uriadu Zakhidno-Ukrainskoi Narodnoi Respubliky u SSHA ta Kanadi. Drohobytskyi kraieznavchyi zbirnyk, 134-153 [in Ukrainian].

10. Spys imenovan u viisku Zakhidnoi Oblasty Ukrainskoi Narodnoi Respublyky, vid dnia 1.XI.1918 pochavshy, do 1 sichnia 1919 vkliuchno. (1919, Sichen 31). Vistnyk Derzhavnoho Sekretariiatu Viiskovykh Sprav, 5, 3 [in Ukrainian].

11. Vidkryttia vystavy USS. (1918, Veresen 17). Dilo, 211 (9771), 2-3 [in Ukrainian].

12. Vistnyk Derzhavnoho Sekretariiatu Viiskovykh Sprav. (1918, Hruden 1), 1, 4

13. Vykazka chet. Ivana Boberskoho, yak referenta Sekretaria Viiskovykh Sprav. (1967). In S. Ripetskyi (Ed.), Za voliu Ukrainy. Istorychnyi zbirnyk USS. V 50-littia zbroinoho vystupu Ukrainskykh Sichovykh Striltsiv proty Moskvy. 1914-1964 (p. 60). New York: Vydannia Holovnoi Upravy Bratstva Ukrainskykh Sichovykh Striltsiv [in Ukrainian].

14. Vystava maliunkiv i svitlyn «Artystychnoi Horstky» i «Presovoi Kvatyry». (1918, Veresen 18). Dilo, 212 (9772), 3 [in Ukrainian].

15. ZUNR, 1918-1923: Iliustrovana istoriia. (2008). Lviv; Ivano-Frankivsk: Manuskrypt [in Ukrainian]. 


\section{Andrii SOVA \\ PhD, Associate Professor, \\ Department of Olympic Education \\ I. Boberskyi Lviv State University of Physical Culture ORCID: https://orcid.org/0000-0003-0548-4975 \\ e-mail:andrijsova@yahoo.com}

\section{IVAN BOBERSKYI AND THE NOVEMBER EVENTS IN LVIV IN 1918}

For the first time, Ivan Boberskyi's participation in the November events 1918 in Lviv was studied based on various sources: documents of the Central State Archives of Supreme Bodies of Power and Government of Ukraine, the Central State Historical Archives of Ukraine in Lviv, the Ukrainian Catholic University, «Zbirka voiennykh drukiv» of the Scientific Library of Ivan Franko Lviv National University; «Dnevnyk» of Ivan Boberskyi; the private archives of Stepan Haiduchok (Lviv); periodicals «Dilo» and «Vistnyk Derzhavnoho Sekretariiatu Viiskovykh Sprav»; memoirs of people who knew Ivan Boberskyi directly or indirectly. Involving previously unavailable and little-known documents, his activities during this period were reconstructed. The author has concluded that Ivan Boberskyi took an active part in the newly created Ukrainian state - the West Ukrainian People's Republic (WUPR). His activities in the State Secretariat for Military Affairs (SSMA) of the West Ukrainian People's Republic under Dmytro Vitovskyi were covered. Much attention is given to his initiatives on establishing the «Chancery Department» of the West Ukrainian People's Republic, which he headed, the development of documentation (rules, posters, orders, statements, information about soldiers' salaries, etc.), work on the «Vistnyk Derzhavnoho Sekretariiatu Viiskovykh Sprav». It is emphasized that his work on photo-recording of events made it possible to leave for descendants documentary evidence of the course of the Polish-Ukrainian war. The research methodology is based on principles of objectivity, reliability, complexity, and scientificity. Given the informativeness, excerpts from Ivan Bobersky's «Dnevnyk» from November 1 to November 21, 1918, were published.

Keywords: Ivan Boberskyi, Lviv, West Ukrainian People's Republic, State Secretariat for Military Affairs of the West Ukrainian People's Republic, «Chancery Department» of the SSMA WUPR, Polish-Ukrainian War 1918-1919. 


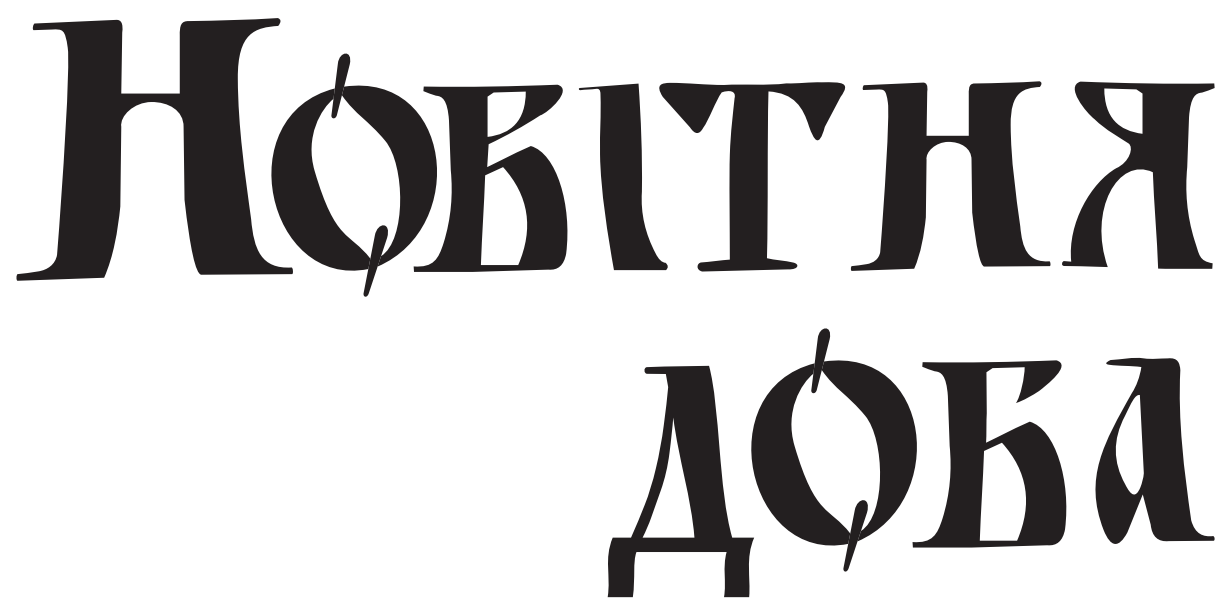

\section{випУСК 8}

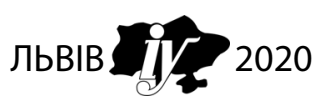


Новітня доба / гол. ред. Михайло Романюк; НАН України, Інститут українознавства ім. І. Крип'якевича. Львів, 2020. Вип. 8. 256 с.

У збірнику представлено дослідження з новітньої української та світової історії за період від Першої світової війни і до сьогодення. Наголошено на закономірностях й особливостях розвитку суспільно-політичних і націєтворчих процесів в Україні у контексті історії європейських народів, зокрема становища українського суспільства в умовах тоталітарних режимів. Розкрито особливості українського визвольного руху, воєнної історії, формування державних інституцій, роль культури у становленні громадянського суспільства, вивчення джерел та історичної біографістики.

Contemporary era / resp. ed. Mykhailo Romaniuk; I. Krypiakevych Institute of Ukrainian Studies NAS of Ukraine. Lviv, 2020. Issue 8. 256 p.

The collection presents studies on modern Ukrainian and world history from the First World War to the present. Emphasis is placed on the regularities and features of the development of socio-political and nation-building processes in Ukraine in the context of the European nations' history, in particular the position of Ukrainian society under totalitarian regimes. The features of the Ukrainian liberation movement, military history, formation of state institutions, the role of culture in the development of civil society, the study of sources and historical biography are revealed.

Рекомендувала до друку вчена рада

Інституту українознавства ім. І. Крип'якевича НАН України

(протокол № 9 від 3.12.2020р.)

\section{ГОЛОВНИЙ РЕДАКТОР}

Романюк Михайло Васильович, к.і.н. (Україна)

\section{РЕДАКЦІЙНА КОЛЕГІЯ:}

Голембійовська-Тобіаш Анета (Gołębiowska-Tobiasz Aneta), dr (Польща)

Дзсньковський Томаш (Dzieńkowski Tomasz), dr (Польща)

Красівський Орест Якубович, д.і.н., проф. (Україна)

Муравський Олег Іванович, к.і.н., с.н.с. (Україна)

Пасіцька Оксана Ігорівна, к.і.н. (Україна)

Патер Іван Григорович, д.і.н., проф. (Україна)

Руда Оксана Василівна, к.і.н. (Україна)

Сова Андрій Олегович, к.і.н., доц. (Україна)

Соляр Ігор Ярославович, д.і.н., с.н.с. (Україна)

Стасюк Олександра Йосипівна, к.і.н., с.н.с. (Україна)

Трофимович Лілія Володимирівна, к.і.н., доц. (Украӥна)

Харук Андрій Іванович, д.і.н., проф. (Україна)

Цецик Ярослав Петрович, к.і.н., доц. (Украӥна) 


\section{MICT}

\section{АКТУАЛЬНІ ПРОБЛЕМИ НОВІТНЬОЇ ІСТОРІЇ}

РУДА Оксана. Освітнє питання в діяльності єврейських парламентарів у Законодавчому сеймі Польської держави (1919-1922) . . . . . . . . . . . 3

ПАСІЦЬКА Оксана. «Свій до свого по своє»: сільськогосподарські виставково-ярмаркові заходи в Галичині у 20-30-х роках ХХ століття . . . . 19

СЕНИЦЬКИЙ Віктор. Воєнна округа УПА «Говерля» в період німецької окупації (1943-1944) . . . . . . . . . . . . . . . . 28

ЛУНЬО Євген. Народно-оповідна традиція про знищення польської колонії Пишівка весною 1944 року . . . . . . . . . . . . . . . . . . . . . . 46

STASIUK Oleksandra. The nomination of candidates for deputies as a ritual element of soviet ostensible democracy $\ldots \ldots \ldots \ldots \ldots \ldots \ldots 77$

ЛУЦЬКИЙ Олександр. Двадцятип'ятитомне видання творів Івана Франка: львівський внесок. . . . . . . . . . . . . . . . . . . . . . . 88

ПОПКО Сергій. Участь військовослужбовців Збройних сил України в міжнародних операціях з підтримання миру і безпеки (1992-2018) . . . . 122

KRASIVSKYI Orest, PASICHNYK Vasyl. Dynamics of national identity formation in independent Ukraine . . . . . . . . . . 134

\section{ПОСТАTI}

ПАТЕР Іван. Іван Крип'якевич і наддніпрянська політична еміграція:

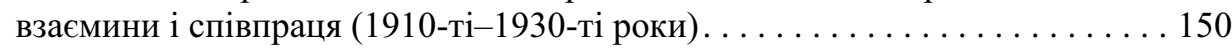

ПОСІВНИЧ Микола. Міжнаціональні стосунки в публіцистиці Степана Бандери. . . . . . . . . . . . . . . . . 178

\section{ПУБЛІКАЦІЯ ДОКУМЕНТІВ}

СОВА Андрій. Іван Боберський і Листопадові події у Львові 1918 року . . . . . 185 ЗАЙЦЕВ Юрій. Шістдесятництво у контексті українського опозиційного руху $1960-1980$-х років. . . . . . . . . 212 


\section{ОГЛЯДИ ТА РЕЦЕНЗЇ̈}

РОМАНЮК Михайло. [Рец.]: Збірник джерел до біографії Романа Шухевича у міжвоєнний період. [на]: Роман Шухевич у громадсько-політичному житті Західної України 1920-1939 рр.: спогади, документи, світлини / упоряд. і відп. ред. Андрій Сова; Центр незалежних історичних студій. Львів: Апріорі, 2019. 816 с. ................................ 239

АРТИМИШИН Юлія. [Рец.]: «(Не)чорно-біла історія українсько-польського діалогу пам'яті». [на]: Стрільчук Л., Нінічук А. Війна пам'яті та війни пам'ятників у сучасних українсько-польських відносинах. Луцьк: Вежа-Друк, 2019. 368 с. . . . . . . . . . . . . . . . . . . . . . . . . 246 